\title{
High Resolution Reference Evapotranspiration for Arid Egypt: comparative analysis and evaluation of empirical and artificial intelligence models
}

Mohamed Tarek Sobh

Arab Academy for Science Technology and Maritime Transport

Mohamed Salem NASHWAN ( $\square$ m.salem@aast.edu )

Arab Academy for Science Technology and Maritime Transport https://orcid.org/0000-0003-40075878

Nabil Amer

Arab Academy for Science Technology and Maritime Transport

\section{Research Article}

Keywords: Potential Evapotranspiration, Machine Learning, MENA, Penman Monteith Equation

Posted Date: February 17th, 2022

DOI: https://doi.org/10.21203/rs.3.rs-1366239/v1

License: (c) (i) This work is licensed under a Creative Commons Attribution 4.0 International License.

Read Full License 
1 High Resolution Reference Evapotranspiration for Arid Egypt: comparative 2 analysis and evaluation of empirical and artificial intelligence models

$4 \quad{ }^{1}$ Construction and Building Engineering Department, College of Engineering and Technology,

5 Arab Academy for Science, Technology and Maritime Transport (AASTMT), B 2401 Smart

6 Village, 12577, Giza, Egypt. E-mail: mohamed.tareksalah@aast.edu (M.T.S),

7 nabil_amer63@aast.edu (N.A)

$8{ }^{2}$ Construction and Building Engineering Department, College of Engineering and Technology,

9 Arab Academy for Science, Technology and Maritime Transport (AASTMT), 2033 Elhorria, 10 Cairo, Egypt. E-mail: m.salem@aast.edu

11

12 *Corresponding Author E-mail: m.salem@aast.edu 


\title{
13 High-Resolution Reference Evapotranspiration for Arid Egypt: comparative
} analysis and evaluation of empirical and artificial intelligence models

\begin{abstract}
Accurate estimation of evapotranspiration has crucial importance in arid regions like Egypt, which suffers from the scarcity of precipitation and water shortages. This study provides an investigation of the performance of 31 widely used empirical equations and 20 models developed using five artificial intelligence (AI) algorithms to estimate reference evapotranspiration $\left(\mathrm{ET}_{\mathrm{o}}\right)$ to generate gridded high-resolution daily ETo estimates over Egypt. The AI algorithms include support vector machine-radial basis function (SVM-RBF), random forest (RF), group method of data handling neural network (GMDH-NN), multivariate adaptive regression splines (MARS), as well as Dynamic Evolving Neural Fuzzy Interference System (DENFIS). Daily observations records of 41 stations distributed over Egypt were used to calculate ETo using FAO56 Penman-Monteith equation as a reference estimate. The multi-parameter Kling-Gupta efficiency (KGE) metric was used as an evaluation metric for its robustness in representing different statistical error/agreement characteristics in a single value. By category, the empirical equations based on radiation performed better in replication FAO56-PM followed by temperature- and mass-transfer-based ones. Ritchie equation was found to be the best overall in Egypt (median KGE 0.75) followed by Caprio (median KGE 0.65), and Penman (median KGE 0.52) equations based on station-wise ranking. On the other hand, the RF model, having maximum and minimum temperatures, wind speed, and relative humidity as predictors, outperformed other AI algorithms. The generated $0.10^{\circ} \times 0.10^{\circ}$ daily estimates of $\mathrm{ET}_{\mathrm{o}}$ enabled the detection of a significant increase of $0.12-0.16 \mathrm{~mm} / \mathrm{decade}$ in the agricultural-dependent Nile Delta using the modified Mann Kendall test and Sen's slope estimator.
\end{abstract}

Keywords: Potential Evapotranspiration; Machine Learning; MENA; Penman Monteith Equation 


\section{Introduction}

39 One of the most crucial issues in water management over the past few decades has been the rarity of water availability in some regions of the world and the difficulty of accurately assessing agricultural demand (Shahid 2011). To overcome these issues and improve water use efficiency, an accurate estimation of Evapotranspiration (ET) is required. ET is a combined process of water transfer from the soil-plant system to the atmosphere by evaporation and transpiration. It plays an important role in irrigation management (Adnan et al. 2021), agricultural planning (Ismail et al. 2017; Mehdizadeh et al. 2017), water stress assessment (Mohsenipour et al. 2018; Sanikhani et al. 2019), and climatological change (Roudier et al. 2014; Yu et al. 2020), as it is a key element of Earth's water cycle.

The most accepted method of estimating ET is by measuring reference evapotranspiration $\left(\mathrm{ET}_{\mathrm{o}}\right) . \mathrm{ET}_{\mathrm{o}}$ is the rate of evapotranspiration from a specific crop, mostly grass or alfalfa under certain conditions (Irmak et al. 2003). Its concept is ascended to avoid variability of evaporation parameters among crops and at different growth stages (Gonzalez del Cerro et al. 2021). However, measuring $\mathrm{ET}_{\mathrm{o}}$ in-situ is not only expensive and time-consuming but also subjective to different degrees of uncertainty. Thus, several empirical equations of estimating of $\mathrm{ET}_{\mathrm{o}}$ have been developed. Among them, the Food and Agriculture Organization (FAO) recommended the Penman-Monteith equation (FAO56-PM) as a standard method for reliable estimation of ETo (Allen et al. 1998). The performance of the FAO56-PM equation is universally accepted as the most skillful equation in estimating $\mathrm{ET}_{0}$. It requires mainly five climatic variables (e.g., temperature, relative humidity, wind speed, solar radiation, and saturated vapor pressure) which limits its use as records of these data are not commonly available especially in data-scarce regions. Thus, several alternative empirical equations are used that require fewer climate records. The performance of the alternative equations depends mainly on climate characteristic patterns which have a significant impact on the estimations (Adnan et al. 2021). Besides, soft computing techniques based on artificial intelligence (AI) algorithms have been widely used to reliably estimate $\mathrm{ET}_{\mathrm{o}}$ from available and recorded meteorological variables (Alizamir et al. 2020). This is driven by the improvement of computer-aided hydrology and water resources models throughout the previous few years (Khosravinia et al., 2020). 
67 In the literature, several studies examined the performance of empirical equations and AI models

68 to select the most robust in estimating $\mathrm{ET}_{\mathrm{o}}$ in different parts of the globe (Gavili et al. 2018;

69 Muhammad et al. 2019). Mehdizadeh et al. (2017) evaluated 16 empirical equations and four AI

70 algorithms (namely gene expression programming (GEP), two different types of Support vector

71 machine (SVM), and multivariate adaptive regression splines (MARS)) in estimating monthly ET $_{0}$

72 in Iran. They found that MARS performed better compared to others. Mattar (2018) tested the

73 performance of GEP models in estimating monthly ETo in Egypt and reported the importance of

74 including mean relative humidity $(\mathrm{RH})$ and wind speed at $2 \mathrm{~m}$ height $\left(\mathrm{U}_{2}\right)$ as predictors in modeling

75 ETo in Egypt. Salam et al. (2020) used 13 empirical equations and Random Forest (RF) algorithm

76 to estimate monthly $\mathrm{ET}_{\mathrm{o}}$ in Bangladesh and found that the Abtew (1996) model has the closest

77 estimates and the best linear correlation with FAO56-PM. Recently, Adnan et al. (2021) proved

78 the feasibility of the group method of data handling neural network (GMDH-NN) which used

79 temperatures records as a predictor and found its high performance in Turkey compared to MARS

80 and other empirical equations.

Egypt, as an arid country, is suffering from severe water scarcity. Precipitation can reach 200 $\mathrm{mm}$ annually in a narrow strip along the Mediterranean shores. Otherwise, this amount drastically reduces to below $5 \mathrm{~mm}$ in inland areas (Hamed et al. 2021c). The Nile supplies Egypt with 98\% of its renewable water resource which is mainly consumed in agricultural activities (Hamed 2019). Meanwhile, Egypt is facing external pressure on its perceived Nile water share due to the construction of the Ethiopian Grand Renaissance dam at the far upstream (Sharaky et al. 2019).

87 Furthermore, it faces internal pressure on water due to rapid growth in population and economic status in recent years (Nikiel and Eltahir 2021). This has spurred the country to control and manage its water resources prudently to improve water (re)usage and especially agriculture productivity and food security (AbuZeid 2020; Nikiel and Eltahir 2021).

This study aims to develop a high resolution $0.10^{\circ} \times 0.10^{\circ}$ estimate of $\mathrm{ET}_{\mathrm{o}}$ for arid Egypt. In order to gain an accurate estimation of $\mathrm{ET}_{\mathrm{o}}, 31$ empirical equations and $20 \mathrm{AI}$ models were evaluated against the FAO56-PM estimates at 41 station locations. The multi-parameter Kling-

94 Gupta efficiency (KGE) metric was used as an evaluation metric for its robustness in representing different statistical error/agreement characteristics in a single value. Then, the best method found was chosen to develop the high-resolution $\mathrm{ET}_{\mathrm{o}}$ data for Egypt. Finally, the rate of change in 
97 historical $\mathrm{ET}_{\mathrm{o}}$ was calculated and tested for significance to assess the spatial pattern of trend in $98 \mathrm{ET}_{\mathrm{o}}$. This study is among the leading approaches in evaluating several empirical and AI models 99 for $\mathrm{ET}_{\mathrm{o}}$ estimation in Egypt. The findings of this study may facilitate an opportunity for improving 100 crop water estimation and reducing internal pressure on water supply in general.

101 2. Study area and data sources

102 2.1. Study area

103 Egypt covers a land area of nearly 1 million $\mathrm{km}^{2}$. Most of the land is flat however the elevation 104 varies from - $139 \mathrm{~m}$ in the Qattara Depression in the North to about $2614 \mathrm{~m}$ in the elevated 105 mountains in Sinai and $1356 \mathrm{~m}$ in the Red Sea Mountains chain, as can be seen in Figure 1. The 106 Nile divides Egypt's land into eastern and western Deserts. These deserts represent most of Egypt's 107 area. Egypt is an arid country. It has mild cold winters, hot summers, and rainfall is rare. The 108 annual rainfall is about $200 \mathrm{~mm} /$ year in the northern parts and less than $5 \mathrm{~mm} /$ year in the far south 109 (Hamed et al. 2021a; Hamed et al. 2021b; Nashwan et al. 2020; Yassen et al. 2020). Due to the 110 shortage of water, most Egyptian live along the Nile in nearly 4\% of Egypt's total land. 111 Agricultural land represents about $3 \%$ of the total area of the nation, located along the Nile valley 112 and its delta. Cultivated land in Egypt occupies $85 \%$ of the total area of arable land (Omran and 113 Negm 2020). 


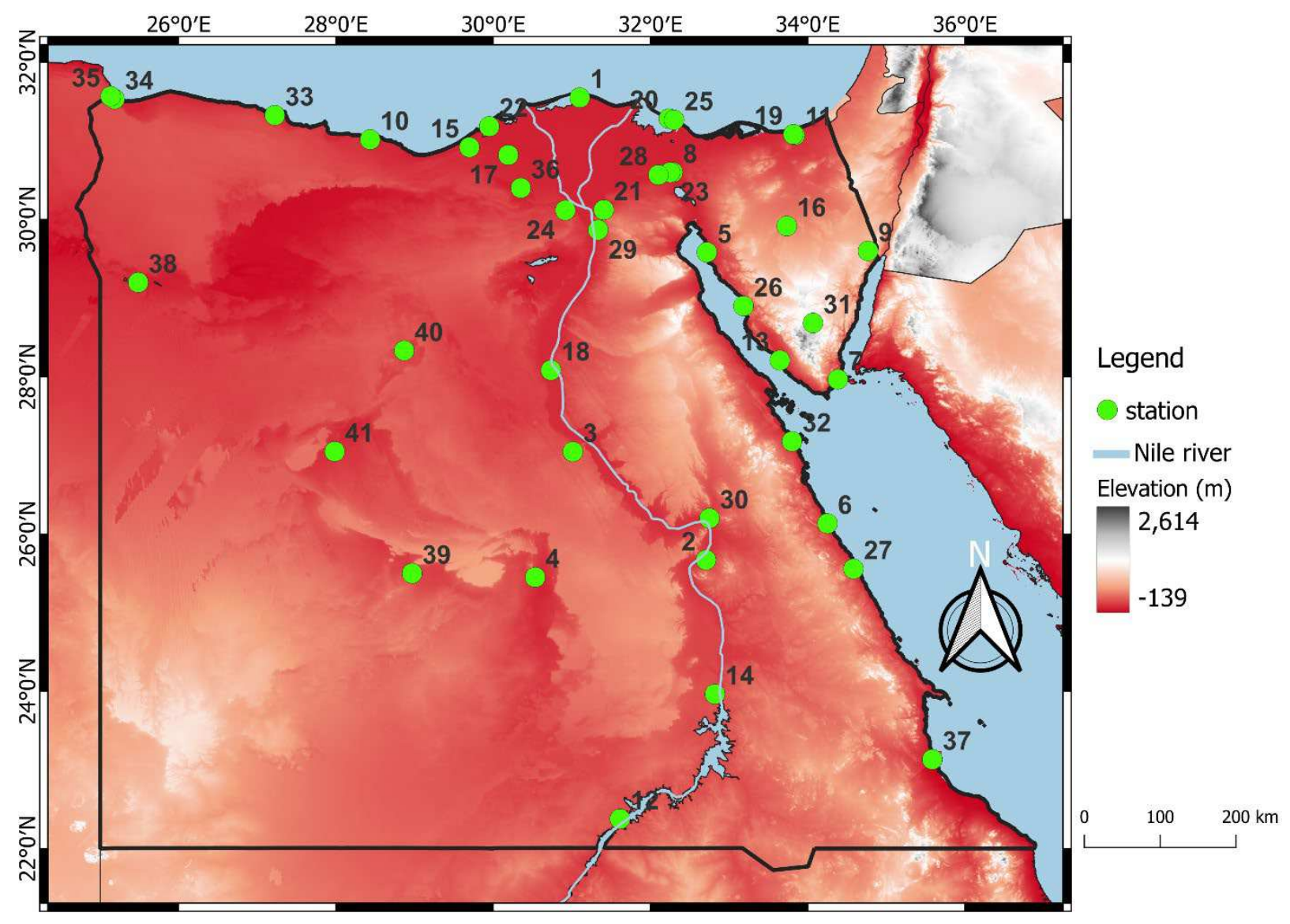

Figure 1. Topography and meteorological stations' locations in Egypt.

\subsection{Data and sources}

117 This study employed two types of data: gauge records and reanalysis gridded data. Daily 118 meteorological observation records at 41-gauge stations distributed all over Egypt's land were 119 collected from the National oceanic and atmospheric administration (NOAA) Global Summary of 120 Days (GSOD) dataset. The records contain observations of maximum, minimum, mean, and 121 dewpoint temperatures ( $\mathrm{T}_{\max }, \mathrm{T}_{\min }, \mathrm{T}_{\text {mean, }}$, and $\mathrm{T}_{\mathrm{dew}}$, respectively), and wind speed $\left(\mathrm{U}_{2}\right)$. The gauges' 122 locations are shown in Figure 1 and descriptive statistics of the records are listed in Table 1.

Table 1. Descriptive statistics of the station records used in the study.

\begin{tabular}{lllllll}
\hline No. & WMO ID & Data range & $\mathrm{T}_{\max }\left({ }^{\circ} \mathrm{C}\right)$ & $\mathrm{T}_{\min }\left({ }^{\circ} \mathrm{C}\right)$ & $\mathrm{T}_{\text {dew }}\left({ }^{\circ} \mathrm{C}\right)$ & $\mathrm{U}_{2}(\mathrm{~m} / \mathrm{s})$ \\
\hline 1 & 623250 & $1994-2021$ & 24.76 & 17.06 & 15.18 & 2.67 \\
2 & 624050 & $1943-2021$ & 33.53 & 16.77 & 8.76 & 4.04 \\
3 & 623930 & $1957-2021$ & 30.32 & 15.75 & 7.26 & 7.82 \\
4 & 624350 & $1957-2021$ & 32.68 & 16.88 & 7.93 & 16.72 \\
5 & 624550 & $1999-2021$ & 28.92 & 17.47 & 12.08 & 3.06
\end{tabular}




\begin{tabular}{lllllll}
\hline No. & WMO ID & Data range & $\mathrm{T}_{\max }\left({ }^{\circ} \mathrm{C}\right)$ & $\mathrm{T}_{\min }\left({ }^{\circ} \mathrm{C}\right)$ & $\mathrm{T}_{\text {dew }}\left({ }^{\circ} \mathrm{C}\right)$ & $\mathrm{U}_{2}(\mathrm{~m} / \mathrm{s})$ \\
\hline 6 & 624650 & $1959-2018$ & 28.20 & 21.24 & 13.50 & 7.81 \\
7 & 624639 & $1997-2021$ & 30.63 & 22.07 & 10.44 & 4.97 \\
8 & 624410 & $1981-1987$ & 28.13 & 15.28 & 12.68 & 7.33 \\
9 & 624655 & $2003-2014$ & 26.90 & 13.16 & 6.31 & 4.48 \\
10 & 623090 & $1960-2021$ & 25.06 & 15.99 & 13.43 & 3.52 \\
11 & 623370 & $1985-2019$ & 26.54 & 14.53 & 13.79 & 2.66 \\
12 & 624190 & $2006-2021$ & 33.71 & 19.19 & 5.22 & 3.52 \\
13 & 624590 & $1959-2021$ & 28.20 & 18.30 & 13.40 & 6.63 \\
14 & 624140 & $1957-2020$ & 34.21 & 19.56 & 3.76 & 7.59 \\
15 & 623601 & $2004-2021$ & 25.37 & 15.68 & 14.11 & 4.20 \\
16 & 624520 & $2001-2021$ & 27.31 & 10.64 & 7.70 & 3.37 \\
17 & 624620 & $1957-1990$ & 28.03 & 18.92 & 11.60 & 10.99 \\
18 & 623870 & $1957-2021$ & 30.07 & 14.82 & 10.89 & 11.77 \\
19 & 623360 & $1958-1998$ & 26.90 & 16.16 & 15.45 & 4.21 \\
20 & 623320 & $1987-2004$ & 24.48 & 18.58 & 15.50 & 6.81 \\
21 & 623660 & $1943-2021$ & 27.93 & 16.51 & 11.70 & 3.76 \\
22 & 623180 & $1957-2021$ & 25.23 & 16.22 & 14.22 & 5.63 \\
23 & 624400 & $1943-2021$ & 27.72 & 15.35 & 12.63 & 3.84 \\
24 & 623680 & $1973-1979$ & 26.90 & 14.81 & 10.24 & 3.69 \\
25 & 623330 & $1957-2021$ & 24.41 & 18.83 & 15.66 & 8.60 \\
26 & 624580 & $2002-2021$ & 27.99 & 18.12 & 11.61 & 3.39 \\
27 & 623661 & $2004-2021$ & 29.29 & 21.93 & 10.18 & 5.54 \\
28 & 624380 & $1959-1966$ & 28.66 & 15.29 & 11.72 & 5.53 \\
29 & 623780 & $1961-1966$ & 27.82 & 15.30 & 9.32 & 4.81 \\
30 & 624030 & $2004-2017$ & 33.19 & 18.42 & 4.48 & 2.58 \\
31 & 623664 & $2007-2021$ & 24.41 & 12.11 & 2.23 & 2.92 \\
32 & 624630 & $1990-2021$ & 30.49 & 19.96 & 10.43 & 7.12 \\
33 & 623060 & $1944-2021$ & 24.39 & 15.51 & 13.55 & 8.81 \\
34 & 623000 & $1957-1995$ & 25.54 & 16.77 & 12.67 & 8.39 \\
35 & 623050 & $1995-2021$ & 24.09 & 14.03 & 11.70 & 4.82 \\
36 & 623570 & $1996-2021$ & 27.65 & 14.89 & 12.33 & 2.89 \\
37 & 624760 & $2003-2019$ & 31.56 & 21.59 & 15.56 & 3.92 \\
38 & 624170 & $1957-2020$ & 29.48 & 14.97 & 8.54 & 4.65 \\
39 & 624320 & $1957-2020$ & 31.42 & 14.46 & 6.08 & 4.31 \\
40 & 624200 & $1957-2021$ & 30.32 & 15.06 & 8.15 & 7.84 \\
41 & 624230 & $1957-2019$ & 30.75 & 15.09 & 5.97 & 11.46 \\
\hline & & & & & &
\end{tabular}

124

125 Using reanalysis as a scientific process, an accurate representation of the weather and 126 climate at regular intervals over a longer period can be obtained. European Reanalysis v.5 (ERA5) 127 data is a combination of a numerical prediction model with satellite observation data and other 128 available gauge records. The results of a reanalysis are meteorological fields in a uniform grid with 129 a reasonable temporal resolution over an extended time period that can provide knowledge on 
130 climate conditions (Lompar et al. 2019). ERA5 is the newest edition, which is the fifth overall 131 developed by European Centre for Medium-Range Weather Forecasts (ECMWF). The Integrated 132 Forecasting System (IFS) cycle 41r2 was used to generate ERA5. Gleixner et al. (2020) evaluated 133 ERA5 temperature data compared to observation data. The results show, over Northern and 134 Southern Africa, the correlation is greater than 0.95. Several surface parameters found in ERA5 135 land were used in this study, such as temperature, dew point temperature, and wind speed from 1361981 to 2020 . The daily data of ERA5 provided high resolution $0.10^{\circ} \times 0.10^{\circ}(\sim 9 \mathrm{~km})$ grid 137 spacing. Data from ERA5 is accessible from 1981 up to 2-3 months before the current time. 138 Despite the progress that has occurred in model expansion, the potential evaporation field provided 139 in ERA5 is largely underestimated over deserts due to an error in the code, which prevents 140 transpiration when there is no or little vegetation. This limits the use of ERA5 potential evaporation in Egypt and brings the need to develop an accurate high-resolution estimate of ETo over Egypt.

\section{Methodology}

143 Figure 2 represents a flowchart of the study methodology. Firstly, the FAO56-PM equation was 144 used to calculate $\mathrm{ET}_{\mathrm{o}}$ at different locations for the available observations records. Then, the resulting $\mathrm{ET}_{\mathrm{o}}$ was used as a reference to evaluate the performance of 31 empirical equations and

14620 models developed using five AI algorithms. For each AI algorithm, four models were 147 developed. The $1^{\text {st }}$ model employed $\mathrm{T}_{\max }$ and $\mathrm{T}_{\min }$ as input variables to estimate reference $\mathrm{ET}_{\mathrm{o}}$. The $1482^{\text {nd }}$ model employed $T_{\max }, T_{\min }$, and $\mathrm{U}_{2}$, whereas the $3^{\text {rd }}$ model employed $R H$ instead of $U_{2}$. Finally, 149 the $4^{\text {th }}$ model employed $T_{\max }, T_{\min }, \mathrm{U}_{2}$, and $\mathrm{RH}$. Random samples represent $70 \%$ of the available 150 records of all stations were used to train different models and the remaining $30 \%$ were used for 151 testing model performances. The multi-parameter Kling-Gupta efficiency (KGE) metric was used 152 as an evaluation metric for its robustness in representing different statistical error/agreement 153 characteristics in a single value. Afterward, the best performing equation/model was selected and 154 used to estimate $\mathrm{ET}_{\mathrm{o}}$ at ungauged locations over Egypt using ERA5 data at $0.10^{\circ} \times 0.10^{\circ}$ spatial 155 resolution. Finally, the rate of change in annual ETo for 1981-2020 was calculated using Sen's 156 slope and significance in change was tested using the modified Mann-Kendal test. 


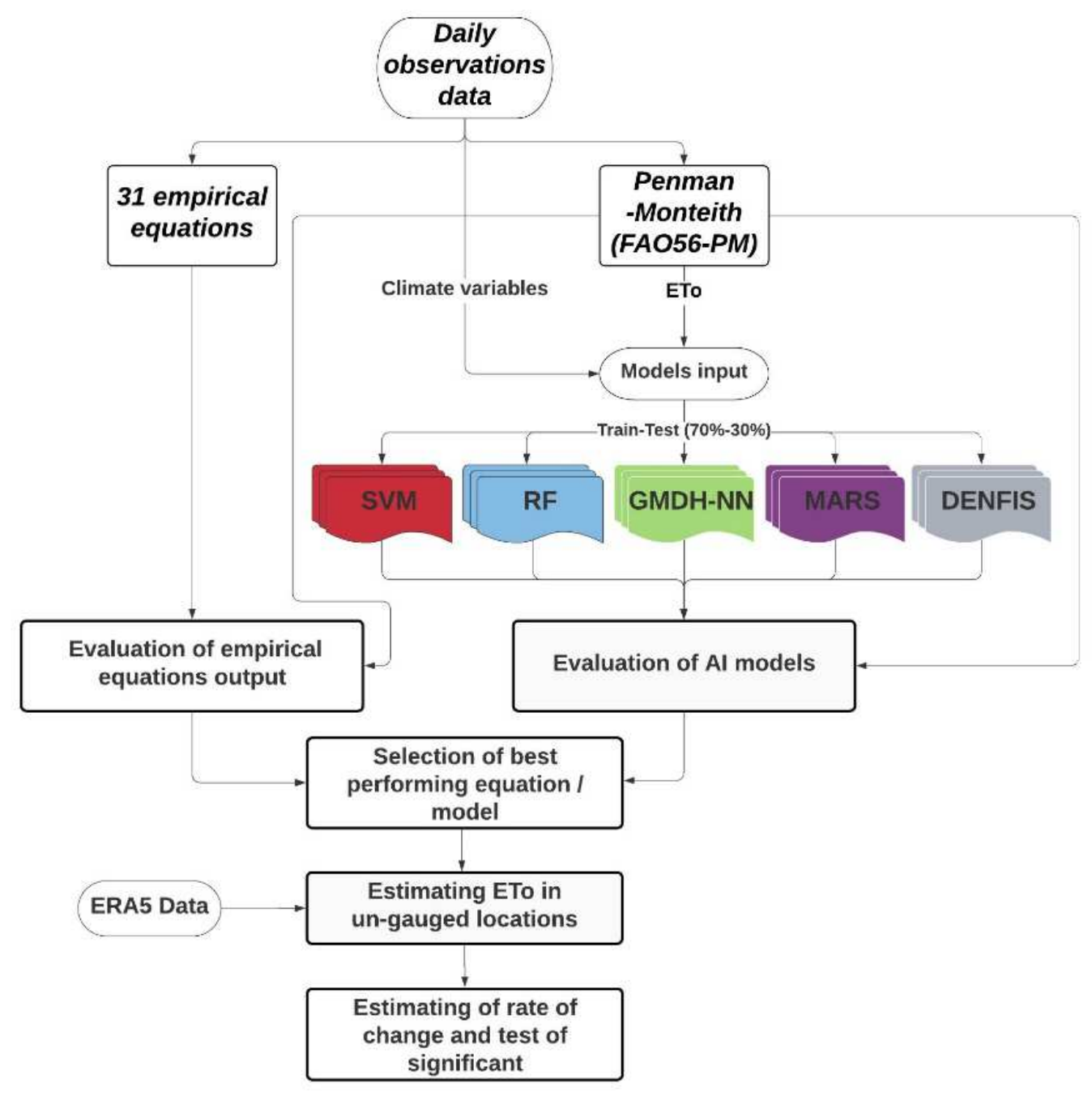

Figure 2. Flowchart of this study's methodology.

159 3.1. Penman-Monteith equation

160 The Penman-Monteith equation (FAO56-PM) is an energy balance physical-based equation to 161 estimate $\mathrm{ET}_{\mathrm{o}}$ proposed by Allen et al. (1998) and recommended by the food and agriculture 162 organization (FAO). The performance of the FAO56-PM equation is universally accepted as the 163 most skillful equation in estimating $\mathrm{ET}_{\mathrm{o}}$. Due to the limited availability and absence of 164 experimental $\mathrm{ET}_{\mathrm{o}}$ in Egypt, the FAO56-PM equation was used as a reference to evaluate the 165 empirical and AI models. However, it requires numerous climatic parameters which are hard to 166 obtain in the data-scarce region as Egypt. The FAO56-PM formula is given in Equation 1:

$$
E T_{o}=\frac{0.408 \times \Delta\left(R_{n}-\mathrm{G}\right)+\gamma \frac{900}{\left(T_{\text {mean }}+273\right)} \times U_{2}\left(e_{s}-e_{a}\right)}{\Delta+\gamma\left(1+0.34 U_{2}\right)}
$$


167 where $\mathrm{ET}_{\mathrm{o}}$ is in $\mathrm{mm} /$ day. $\Delta$ is the slope of the saturation vapor pressure-temperature curve $168\left(\mathrm{KPa} /{ }^{\circ} \mathrm{C}\right) . R_{n}$ is net radiation $\left(\mathrm{MJ} / \mathrm{m}^{2} /\right.$ day $) . \mathrm{G}$ is the soil heat flux $\left(\mathrm{MJ} / \mathrm{m}^{2} /\right.$ day $) . \gamma$ is the 169 Psychometric constant $\left(\mathrm{KPa} /{ }^{\circ} \mathrm{C}\right) . T_{\text {mean }}$ is the mean air temperature at $2 \mathrm{~m}$ height $\left({ }^{\circ} \mathrm{C}\right) . U_{2}$ is the 170 wind speed at $2 \mathrm{~m}$ height $(\mathrm{m} / \mathrm{s}) . \mathrm{e}_{\mathrm{s}}$ and $\mathrm{e}_{\mathrm{a}}$ are the saturation and actual vapor pressure $(\mathrm{KPa})$.

172 duration to determine daily global irradiance for a horizontal surface. Bojanowski et al. (2013)

173 developed satellite-based calibration of the calibration coefficients (i.e. a and b) in Angstrom-

174 Prescott model which has led to high accuracy for estimating solar radiation compared to 175 interpolated ground-based model coefficients. Thus, this study used these site-specific 176 coefficients of the model to obtain more accurate estimation of solar radiation over Egypt leading 177 to better estimation of FAO65-PM ET 0 . Furthermore, the sunshine hours $(n)$ were derived using 178 the linear regression proposed Abd el-wahed and Snyder (2015) (expressed in Equation 2) which 179 was developed for reliable estimation of $n$ for arid climate and desert locations.

$$
n=4.352+0.232 T_{\text {mean }}
$$

\subsection{Empirical estimation of $\mathbf{E T}_{\mathrm{o}}$}

181 A bundle of 31 empirical equations to estimate ETo was evaluated in this study. They are 182 categorized based on their bases; namely, temperature-, radiation-, and mass transfer-based 183 equations. They are listed in Table 2 where equations 3-13, 14-23, and 24-33 are temperature-, 184 radiation-, and mass-transfer-based equations, respectively. This bundle of equations is widely and 185 commonly used to estimate $\mathrm{ET}_{\mathrm{o}}$ empirically for different climates and regions (Sharafi and Ghaleni 186 2021).

187 Table 2. Empirical equations were used in this study. Equations 3-13, 14-23, and 24-33 are 188 temperature-, radiation-, and mass-transfer-based equations, respectively.

\begin{tabular}{|c|c|c|c|}
\hline Model & Parameter & Equation & \\
\hline $\begin{array}{l}\text { Baier and } \\
\text { Robertson } \\
\text { (Baier and } \\
\text { Robertson 1965) }\end{array}$ & $T_{\max }, T_{\min }$ & $\begin{aligned} E T_{o}=0.109 \times & \left(\frac{R_{a}}{\lambda}\right)+0.157 T_{\max } \\
& +0.158\left(T_{\max }-T_{\min }\right)-5.39\end{aligned}$ & (3) \\
\hline $\begin{array}{l}\text { FAO Blaney- } \\
\text { Criddle } \\
\text { (Doorenbos and } \\
\text { Pruitt 1977) }\end{array}$ & $T_{\text {mean }}$ & $E T_{o}=p\left(0.46 T_{\text {mean }}+8.13\right)$ & (4) \\
\hline Hamon (1963) & $T_{\text {mean }}$ & $E T_{o}=0.1651 L_{d} R H O S A T \times K P E C$ & $(5)$ \\
\hline
\end{tabular}




\begin{tabular}{|c|c|c|c|}
\hline Model & Parameter & Equation & \\
\hline $\begin{array}{l}\text { Hargreaves and } \\
\text { Samani (1985) }\end{array}$ & $\begin{array}{l}T_{\text {mean }} \\
T_{\min }, T_{\max } \\
R_{a}\end{array}$ & $E T_{o}=\left(0.0023 \frac{R_{a}}{2.45}\right) T D^{0.5}\left(T_{\text {mean }}+17.8\right)$ & $(6)$ \\
\hline $\begin{array}{l}\text { Ivanov } \\
\text { (Romanenko } \\
\text { 1961) }\end{array}$ & $T_{\text {mean }}, \mathrm{RH}$ & $E T_{o}=0.00006\left(25+T_{\text {mean }}\right)^{2}(100-R H)$ & (7) \\
\hline Kharrufa (1985) & $T_{\text {mean }}$ & $E T_{o}=0.34 P T_{\text {mean }}{ }^{1.3}$ & $(8)$ \\
\hline Linacre (1977) & $T_{\text {mean }}$ & $E T_{o}=\frac{\frac{700\left(T_{\text {mean }} \pm 0.006 Z\right)}{100-L}+\left(15 T_{\text {mean }}-T_{d}\right)}{80-T_{\text {mean }}}$ & $(9)$ \\
\hline $\begin{array}{l}\text { Papadakis } \\
(1965)\end{array}$ & $T_{\text {mean }}, \mathrm{RH}$ & $E T_{0}=2.5\left(e_{m a}-e_{a}\right)$ & $(10)$ \\
\hline $\begin{array}{l}\text { Ravazzani et al. } \\
(2011)\end{array}$ & $\begin{array}{l}T_{\text {mean }}, \\
T_{\text {min }}, T_{\text {max }} \\
R_{a}\end{array}$ & $\begin{array}{l}E T_{o} \\
=(0.817+0.00022 Z)\left(0.0023 R_{a}\right)\left(T D^{0.5}\right)\left(T_{\text {mean }}\right. \\
+17.8)\end{array}$ & $(11)$ \\
\hline Schendel (1967) & $T_{\text {mean }}, \mathrm{RH}$ & $E T_{o}=16\left(\frac{T_{\text {mean }}}{R H}\right)$ & $(12)$ \\
\hline Trajkovic (2007) & $\begin{array}{l}T_{\text {mean }} \\
T_{\min }, T_{\max } \\
R_{a}\end{array}$ & $E T_{o}=\left(0.0023 R_{a}\right) T D^{0.424}\left(T_{\text {mean }}+17.8\right)$ & $(13)$ \\
\hline Abtew (1996) & $T_{\text {mean }}, R_{s}$ & $E T_{o}=0.53\left(\frac{R_{s}}{\lambda}\right)$ & $(14)$ \\
\hline Caprio (1974) & $T_{\text {mean }}, R_{s}$ & $E T_{o}=\left(\frac{6.1}{10^{6}}\right) R_{s}\left(1.8 T_{\text {mean }}+1\right)$ & $(15)$ \\
\hline $\begin{array}{l}\text { Irmak et al. } \\
(2003)-\text { Rs }\end{array}$ & $\begin{array}{l}T_{\text {mean }}, R_{S}, \\
\mathrm{RH}\end{array}$ & $E T_{o}=0.489+0.289 R_{n}+0.023 T_{\text {mean }}$ & $(16)$ \\
\hline $\begin{array}{l}\text { Irmak et al. } \\
(2003)-\mathrm{Rn}\end{array}$ & $T_{\text {mean }}, R_{s}$ & $E T_{o}=-0.611+0.149 R_{s}+0.079 T_{\text {mean }}$ & $(17)$ \\
\hline $\begin{array}{l}\text { Jensen and } \\
\text { Haise (1963) }\end{array}$ & $T_{\text {mean }}, R_{s}$ & $E T_{o}=\left(\frac{R_{s}}{\lambda}\right)\left(0.025 T_{\text {mean }}+0.08\right)$ & $(18)$ \\
\hline $\begin{array}{l}\text { Ritchie et al. } \\
\text { (Jones 1990) }\end{array}$ & $\begin{array}{l}T_{\min }, T_{\max } \\
R_{s}\end{array}$ & $\begin{aligned} E T_{o}=\alpha_{1}(3.87 & \\
& \left.\times 10^{-3}\right)\left(R_{s}\left(0.6 T_{\text {max }}+0.4 T_{\text {min }}\right.\right. \\
& +29))\end{aligned}$ & $(19)$ \\
\hline Makkink (1957) & $T_{\text {mean }}, \mathrm{R}_{\mathrm{s}}$ & $E T_{o}=0.61\left(\frac{\Delta}{\Delta+\gamma}\right) \frac{R_{s}}{58.5}-0.12$ & $(20)$ \\
\hline $\begin{array}{l}\text { McGuinness and } \\
\text { Bordne (1972) }\end{array}$ & $T_{\text {mean }}, R_{s}$ & $E T_{o}=\left(0.0082 T_{\text {mean }}-0.19\right) \frac{R_{s}}{1500}(2.54)$ & $(21)$ \\
\hline $\begin{array}{l}\text { Priestley and } \\
\text { Taylor (1972) }\end{array}$ & $\begin{array}{l}T_{\text {mean }}, R_{s} \\
\mathrm{RH}\end{array}$ & $E T_{o}=\alpha\left(\frac{\Delta}{\Delta+\gamma}\right) \frac{R_{n}}{\lambda}$ & $(22)$ \\
\hline Turc (1961) & $\begin{array}{l}T_{\text {mean }}, R_{S} \\
\mathrm{RH}\end{array}$ & $E T_{o}=0.013\left(\frac{T_{\text {mean }}}{T_{\text {mean }}+15}\right)\left(R_{s}+50\right)$ & $(23)$ \\
\hline Albrecht (1950) & $\begin{array}{l}T_{\text {mean }}, \mathrm{RH} \\
\mathrm{U}_{2}\end{array}$ & $E T_{o}=\left(0.1005+0.297\left(U_{2}\right)\right)\left(e_{s}-e_{a}\right)$ & $(24)$ \\
\hline $\begin{array}{l}\text { Brockamp and } \\
\text { Wenner (1963) }\end{array}$ & $\begin{array}{l}T_{\text {mean }}, \mathrm{RH} \\
\mathrm{U}_{2}\end{array}$ & $E T_{o}=0.543\left(U_{2}^{0.456}\right)\left(e_{s}-e_{a}\right)$ & $(25)$ \\
\hline
\end{tabular}




\begin{tabular}{|c|c|c|c|}
\hline Model & Parameter & Equation & \\
\hline Dalton (1802) & $\begin{array}{l}T_{\text {mean }}, \mathrm{RH} \\
\mathrm{U}_{2}\end{array}$ & $E T_{o}=\left(0.3648+0.07223\left(U_{2}\right)\right)\left(e_{s}-e_{a}\right)$ & (26) \\
\hline $\begin{array}{l}\text { Mahringer } \\
(1970)\end{array}$ & $\begin{array}{l}T_{\text {mean }}, \mathrm{RH} \\
\mathrm{U}_{2}\end{array}$ & $E T_{o}=(0.15072) \sqrt{3.6 U_{2}}\left(e_{s}-e_{a}\right)$ & $(27)$ \\
\hline Meyer (1926) & $\begin{array}{l}T_{\text {mean }}, \mathrm{RH} \\
\mathrm{U}_{2}\end{array}$ & $E T_{o}=\left(0.375+0.05026\left(U_{2}\right)\right)\left(e_{s}-e_{a}\right)$ & $(28)$ \\
\hline Penman (1948) & $\begin{array}{l}T_{\text {mean }}, \mathrm{RH} \\
\mathrm{U}_{2}\end{array}$ & $E T_{o}=\left(2.625+\frac{0.000479}{U_{2}}\right)\left(e_{s}-e_{a}\right)$ & (29) \\
\hline Rohwer (1931) & $\begin{array}{l}T_{\text {mean }}, \mathrm{RH} \\
\mathrm{U}_{2}\end{array}$ & $E T_{o}=\left(3.3+0.891\left(U_{2}\right)\right)\left(e_{s}-e_{a}\right)$ & $(30)$ \\
\hline Szasz (1973) & $\begin{array}{l}T_{\text {mean }}, \mathrm{RH} \\
\mathrm{U}_{2}\end{array}$ & $E T_{o}=0.00536\left(T_{\text {mean }}+21\right)^{2}(1+R H)^{2 / 3} \mathcal{F}\left(U_{2}\right)$ & (31) \\
\hline Trabert (1896) & $\begin{array}{l}T_{\text {mean }}, \mathrm{RH} \\
\mathrm{U}_{2}\end{array}$ & $E T_{o}=(0.3075) \sqrt{U_{2}}\left(e_{s}-e_{a}\right)$ & (32) \\
\hline $\begin{array}{l}\text { WMO } \\
\text { (Gangopadhyaya } \\
1966 \text { ) }\end{array}$ & $\begin{array}{l}T_{\text {mean }}, \mathrm{RH} \\
\mathrm{U}_{2}\end{array}$ & $E T_{o}=\left(0.1298+0.0934\left(U_{2}\right)\right)\left(e_{s}-e_{a}\right)$ & (33) \\
\hline
\end{tabular}

$\mathrm{ET}_{\mathrm{o}}$ is the reference evapotranspiration in mm/day except for McGuinness and Bordne, and Ritchie equations, ETo in cm/day. $R_{n}$ is net radiation $\left(\mathrm{MJ} / \mathrm{m}^{2} /\right.$ day). $T_{\max }, T_{\text {min }}, T_{\text {mean }}$ and $T_{d}$ are the maximum, minimum, mean, and dewpoint daily air temperature in ${ }^{\circ} \mathrm{C}$ respectively, except $T_{\text {mean }}$ in McGuinness and Bordne equation wherein ${ }^{\circ} \mathrm{F}$. $\mathrm{G}$ is the soil heat flux $\left(\mathrm{MJ} / \mathrm{m}^{2} /\right.$ day). $\gamma$ is 194 the Psychometric constant $\left(\mathrm{KPa} /{ }^{\circ} \mathrm{C}\right) . \mathrm{U}_{2}$ is the mean daily wind speed at $2 \mathrm{~m}$ height. $\mathrm{Z}$ is the elevation in $\mathrm{m} . L$ is the local latitude in degree. $R_{a}$ is extraterrestrial radiation $\left(\mathrm{MJ} / \mathrm{m}^{2} / \mathrm{day}\right) . T D$ is the difference between the $\mathrm{T}_{\max }$ and $\mathrm{T}_{\min }$ in ${ }^{\circ} \mathrm{C} . R_{S}$ is solar radiation in $\mathrm{MJ} / \mathrm{m}^{2} /$ day except in Ritchie, Makkink, Turc, and McGuinness and Bordne equations, $R_{s}$ wherein $\mathrm{Cal} / \mathrm{m}^{2} . e_{s}$ and $e_{a}$ are the saturation and actual vapor pressure $(\mathrm{hPa})$, except for Rohwer, Papadakis and penman are in KPa. $e_{m a}$ is the saturation vapor pressure at monthly mean daily maximum temperature $(\mathrm{KPa}) . \lambda$ is the latent heat of evaporation $(\mathrm{MJ} / \mathrm{Kg}) . \Delta$ is the slope of the saturation vapor pressure-temperature curve $\left(\mathrm{Kpa} /{ }^{\circ} \mathrm{C}\right) . \mathrm{RH}$ is the average relative humidity percentage. $p$ is a constant having two values depending on the number of the month (0.27 and 0.28). $L_{d}$ is the daytime length in multiples of 12 h. $\mathcal{F}\left(U_{2}\right)$ is a function of wind speed. RHOSAT is the saturated vapor density $\left(\mathrm{g} / \mathrm{m}^{3}\right)$. ESAT is the saturated vapor pressure (mbar). KPEC is a calibration coefficient (1.2) and $\alpha$ is a constant (1.26). At Ritchie equation, $\alpha_{1}$ is a coefficient that depends on $T_{\max }$ and calculated as follows:

$$
\text { if } 5^{\circ} \mathrm{C}<T_{\max } \leq 35^{\circ} \mathrm{C}, \alpha_{1}=1.1
$$




$$
\begin{aligned}
& \text { if } T_{\max }>35^{\circ} \mathrm{C}, \alpha_{1}=1.1+0.05\left(T_{\max }-35\right) \\
& \text { if } T_{\max }<5{ }^{\circ} \mathrm{C}, \alpha_{1}=0.01 \times \exp \left[0.18\left(T_{\max }+20\right)\right]
\end{aligned}
$$

\section{3.3. AI models}

208

\subsubsection{Support vector machine}

209 SVM is a machine learning technique that can be used for both classification and regression.

210 SVM's core concept, which is extrapolated to support vector regression (SVR), is to separate two

211 or more classes linearly with a hyperplane, by selecting support vector points. SVR is a powerful

212 forecasting tool for resolving regression issues using the kernel function. ET $_{\mathrm{o}}$ prediction using this

213 technique is obtained using the following formulation.

$$
\hat{y}_{t}=b_{o}+\sum_{i=1}^{N}\left(\alpha_{1}-\alpha_{i}^{*}\right) K\left(\chi_{k}, \chi\right)
$$

214 where $\hat{y}_{t}$ is the target predict variable, $b_{o}$ is bias, $\alpha_{1}, \alpha_{i}^{*}$ are the dual variables, and $K\left(\chi_{k}, \chi\right)$ is the

215 kernel function. The radial basis function kernel (RBF) was used in this study.

216

\section{3.3.2. Random Forest}

$218 \mathrm{RF}$, which is extensively used in different research fields, is an ensemble tree-based method in 219 which trees are trained in a random subset and can be used with bagging or pasting, bagging is 220 more frequent and commonly used. When the number of trees grows, it also brings more 221 randomness and achieves the concept of generalization. Rather than looking for the best 222 characteristic to split a node, it looks for the best feature among a set of random sub-nodes. 223 Randomly various features $\left(m_{\text {try }}\right)$ selected in each split node, and the number of regression trees $224\left(n_{\text {tree }}\right)$ are the parameters used by RF. Prediction obtained by the model after training is 225 represented as:

$$
\hat{y}_{t}=\frac{1}{M} \sum_{m=1}^{M} T_{m}\left(f_{t}\right)
$$

226 where $\mathrm{M}$ is the number of regression trees, $T_{m}$ denotes a single decision tree, and $f_{t}$ is a vector of 227 predictors. 
Root mean square error was used to select the optimal model. Two-fold cross-validation

229

230

231

232

233 was used to calibrate $m_{t r y}$ and the final value used was 3 . The number of regression trees used in this study was $n_{\text {tree }}=500$.

\subsubsection{Group method of data handling neural network (GMDH-NN)}

GMDH-NN is a nonlinear machine learning model with a statistical analysis approach, used for classification and regression problems by identifying the complex relationship between input and output of the system. The GMDH-NN model has the ability to handle several inputs variables and predict a single output, using different layers in the model. Each layer output considers an input to the next layer (Adnan et al. 2021). The GMDH-NN's layer structure can be presented as:

$$
\hat{y}_{t}=a_{o}+\sum_{i=1}^{M} a_{i} x_{i}+\sum_{j=1}^{M} \sum_{i=1}^{M} a_{i} a_{j} x_{i} x_{j}+\sum_{k=1}^{M} \sum_{j=1}^{M} \sum_{i=1}^{M} a_{i} a_{j} a_{k} x_{i} x_{j} x_{k}+\cdots
$$

where $x_{i}=\mathrm{i}^{\text {th }}$ input variable; $\mathrm{M}=$ total number of input variables; and $a_{i}=$ weight associated with $x_{i}$. To minimize the difference between the observed values and the output values generated by GMDH-NN, the weights are optimized using the least-squares method.

\subsubsection{Multivariate adaptive regression splines (MARS)}

MARS is a non-parametric flexible regression model, used to predict persistent numerical target variables. In this algorithm, input variables are separated into intervals, and each interval is fitted with a basis function. The information about independent variables is represented by the basis function. The initial and final points of a basis function are known as knots, and they are defined in a specific range. The MARS model is divided into two stages: In the first stage (forward step), the model uses a constant value to estimate the value of the target variable. This variable is the mean of the data for the target variable. An over-fitted and complex model with a huge number of knots is constructed at this stage. In the second stage (backward step), checking all basis functions added in the first stage is carried out. Finally, the model was obtained (Mehdizadeh et al. 2017). 


\subsubsection{Dynamic Evolving Neural Fuzzy Interference System (DENFIS)}

256 DENFIS is an AI learning algorithm based on an Adaptive Neural Fuzzy Inference Systems 257 (ANFIS) introduced by Kasabov and Qun (2002). DENFIS uses an evolving clustering algorithm 258 that takes into account the greatest possible distance between the points and the center of the 259 cluster. Thus, it can handle the noise in the data (Ye et al. 2022). Furthermore, DENFIS learning approach assesses the position of the input vectors in the feature scape is assessed by fuzzy neural networks and then a dynamic process forms a fuzzy inference system to predict the output based

262 on the nearest fuzzy rules. In comparison to other well-known models, DENFIS showed to be able 263 to learn complex temporal sequences in an adaptable manner (Ye et al. 2022).

\subsection{Evaluation metric}

265

The performances of the empirical equations and the AI models were statistically assessed using

266 the robust KGE metric. The KGE integrates several statistics into one metric and gives an overall 267 score of the skill of each method in estimating the ETo compared to FAO56-PM estimations. As 268 shown in Equation 40, it incorporates three components of observed and simulated data: Pearson's 269 linear correlation $(r)$, coefficient of variability $(\alpha)$, and bias ratio $(\beta)$.

$$
\begin{gathered}
K G E=1-\sqrt{(r-1)^{2}+(\alpha-1)^{2}+(\beta-1)^{2}} \\
\alpha=\frac{\sigma_{\text {sim }}}{\sigma_{\text {obs }}} \\
\beta=\frac{\mu_{\text {sim }}}{\mu_{\text {obs }}}
\end{gathered}
$$

270 where, $\sigma_{\text {sim }}$ is the simulation standard deviation, $\sigma_{o b s}$ is the FAO56-PM standard deviation, $\mu_{\text {sim }}$ 271 is the mean of simulation, and $\mu_{o b s}$ is the mean of FAO56-PM estimations. In case there is a perfect 272 match between the pairs of $\mathrm{ET}_{\mathrm{o}}$ time series, the KGE values shall be one. Otherwise, the KGE 273 values shall be lower than 1 to $-\infty$. A positive KGE value indicates a "good" overall skill, whereas 274 a negative KGE value indicates a "weak" model skill (Knoben et al. 2019). 


\subsection{Trend Analysis}

\subsubsection{Sen's slope estimator}

Sen's slope method (Sen 1968), is a non-parametric statistical method for fitting a line for the mean of the slope. Sen's slope estimator (1968) turned out to be an effective tool for constructing linear relationships. Estimating slopes between series data points as follows:

$$
Q_{i}=\frac{\chi_{j}-\chi_{k}}{j-k} \text { for } i=1: \mathrm{N}
$$

where $Q_{i}$ is the median slope between data points, $\chi_{i}$ and $\chi_{j}$ is measured respectively at $j$ and $k$ (where $j>k$ ). Sen's slope estimator clearly shows the trend over the entire period.

\subsubsection{Modified Mann Kendall test}

Unlike the standard Mann-Kendall test (Kendall 1948; Mann 1945), the modified Mann-Kendall test, proposed by Hamed and Rao (1998), detect the unidirectional trends in time series with the existence of autocorrelations. The main advantage of the modified Mann-Kendall is that it eliminates the influence of long-term persistence in time series on trend significance. Several studies revealed the robustness of the modified Mann-Kendall rather than the standard version in testing the significance of change in climatic time series (Nashwan and Shahid 2019a; Nashwan et al. 2019; Sa'adi et al. 2017). The 95\% confidence level was adopted in this study. Further information regarding the modified Mann-Kendall test can be found in literature, for example in the following references (Iqbal et al. 2019; Sa'adi et al. 2017; Salman et al. 2019; Shahid and Khairulmaini 2009; Sharafati et al. 2019).

\section{Results}

\subsection{Evaluation of empirical equations}

Heat-scatter plots between $\mathrm{ET}_{0}$ observed from FAO56-PM against each simulated $\mathrm{ET}_{0}$ from the empirical equation are shown in Figure 3. As observed in Figure 3, most temperature, radiation, and mass transfer tend to overestimate the simulated $\mathrm{ET}_{\mathrm{o}}$ except Baier and Robertson, and Penman. Radiation-based equations generally have a smaller overestimation than temperature-based equations. The mass-transfer-based equations tend to overestimate $\mathrm{ET}_{\mathrm{o}}>$ than $6 \mathrm{~mm} /$ day expect for Penman equation. On the other hand, the FAO Blaney-Criddle, Abtew, Makkink, McGuinness 
305 and Bordne, Priestley and Taylor, and Turc equations underestimated values of ETo $>6 \mathrm{~mm} / \mathrm{day}$.

306 Overall, temperature, radiation-based equations perform better than mass transfer-based equations, 307 except for the Penman equation which performs better than the other mass-transfer-based 308 equations. Besides, Ritchie equation simulation of $\mathrm{ET}_{\mathrm{o}}$ was better aligned with the diagonal line $309 \quad 1: 1$.

310 

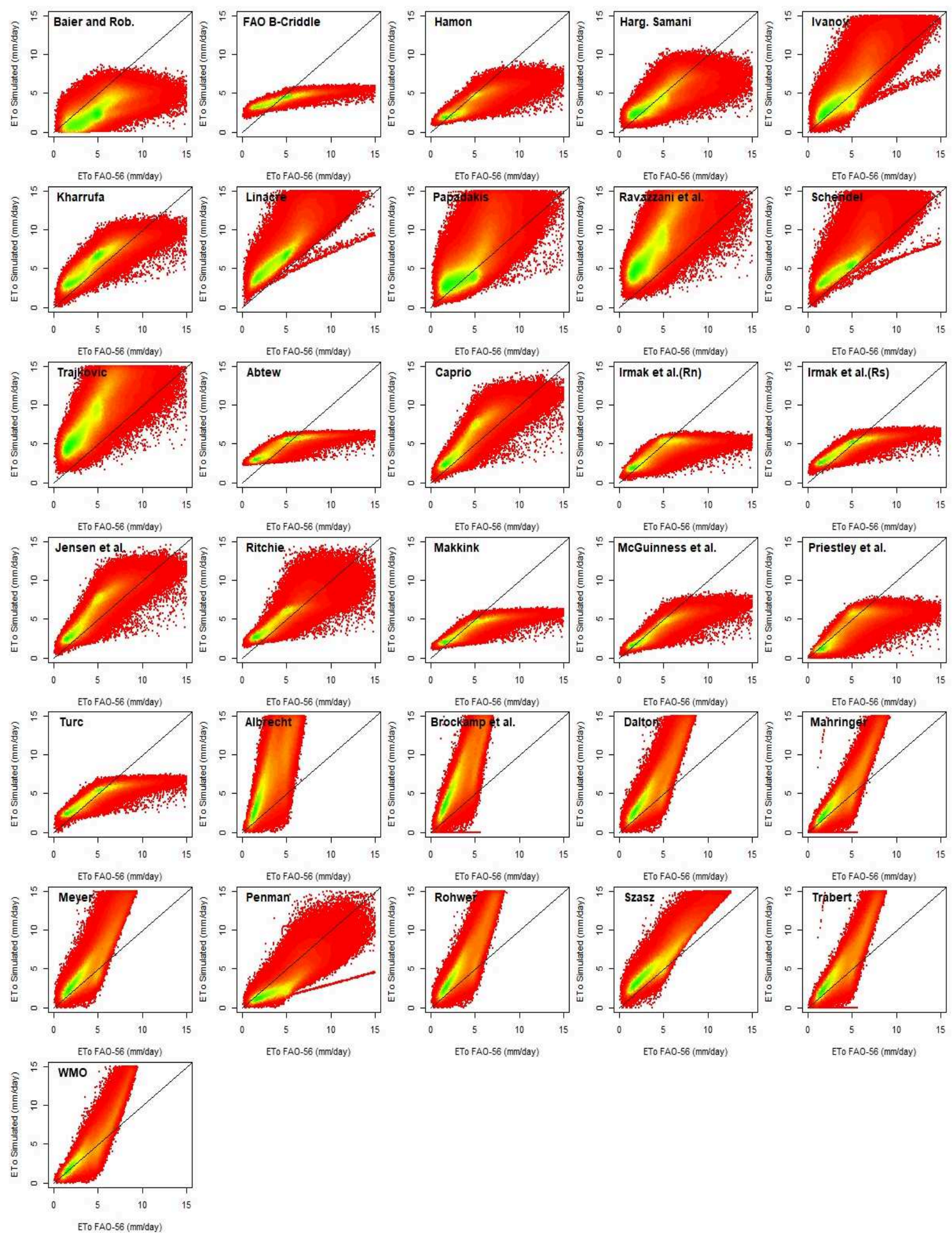

312 Figure 3. Heat scatter plots of different $\mathrm{ET}_{\mathrm{o}}$ empirical equations estimates against $\mathrm{FAO} 56-\mathrm{PM}(\mathrm{n}=$ 313 430688). 


\subsection{Performance evaluation}

315 Figure 4 presents box-and-whiskers plots of KGE scores for the $31 \mathrm{ET}_{\mathrm{o}}$ empirical equations. Plots

316 (a-c) present the components of the KGE, the $r, \alpha$, and $\beta$, aiming at presenting which component

317 effect the final KGE score that is presented in plot (d). The red vertical lines present the optimal

318 value of the scores which is unity. By category, the empirical equations based on mass transfer 319 performed poorly in replicating FAO56-PM estimates compared to the temperature- and radiation320 based equations. The mass-transfer-based equations achieved KGE scores far from unity. Among 321 them, the Penman equation was found the best having a median KGE of 0.52 , and Albrecht was 322 found the worst among all equations (median KGE equals -19.04). The performances of the 323 temperature- and radiation-based equations were comparable. Among the temperature-based 324 equations, Hargreaves-Samani had the highest skill with a median KGE of 0.73. However, Ritchie, 325 radiation-based equation, had better performance than Hargreaves-Samani and was the best among 326 the radiation-based equations having median $\mathrm{r}, \alpha \beta$, and KGE 0.90, 0.80, 1.14, and 0.75, 327 respectively. On the other hand, the mean median scores of the KGE components $r$, $\alpha$, and $\beta$ 328 expressed as $|r-1|,|\alpha-1|$, and $|\beta-1|$, are $0.21,0.80$, and 0.46 , respectively. The mean median 329 score of KGE of all equations is -0.80 and without considering the mass-transfer-based equations 330 results are 0.51 . The empirical equations thus performed remarkably worse in terms of $\alpha$ meaning 331 that bias in estimates is the issue rather than correlation and ratio in co-efficient of variation. In 332 turn, the $\alpha$ value was the dominant component in the final KGE scores due to the squaring of the 333 three components of KGE (refer to Equation 40). 

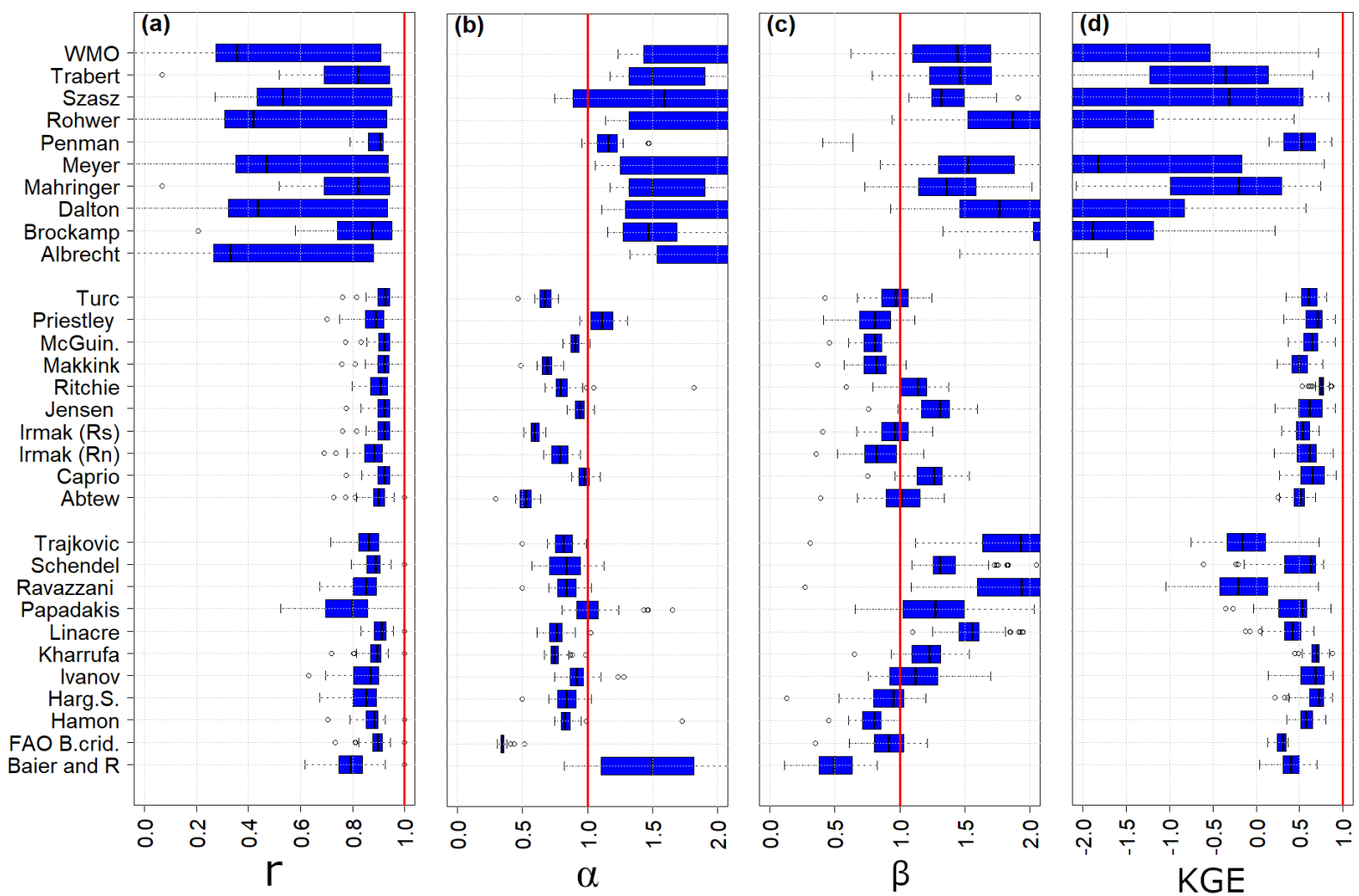

Figure 4. Box-and-whiskers plots of (a) linear correlation $(r)$, (b) coefficient of variability $(\alpha),(\mathrm{c})$ bias ratio $(\beta)$, and (d) Kling-Gupta efficiency (KGE) used for evaluating the 31 empirical equations compared to observed ETo obtained from FAO56-PM. The optimum value is represented by the vertical red line.

KGE scores were ranked at each gauge station location to identify the best empirical equation per location. Out of the 31 equations used, eight equations dominated the top station-wise ranks. Namely, they are Ritchie, Penman, Caprio, Irmak (Rn), Ivanov, Hargreaves Samani, McGuinness, Jensen, Kharrufa, Priestley, and Papadakis, and their spatial distribution is presented in Figure 5. The Ritchie equation was found the best at eight locations, followed by Penman, Caprio, and Irmak (Rn) each at five locations, then Ivanov and Hargreaves-Samani each at four locations, McGuinness, and Jensen each at three locations, Kharrufa at two locations and finally Priestley, and Papadakis each at one location. Furthermore, the figure also shows the distribution of the type of each best equation per location. It can be seen that there is a spatial pattern in equation type over Egypt. The radiation-based equation dominated the majority of Egypt (25 out of 41 locations: 61\%). The temperature-based equations dominated the northern west edge of the country where solar radiation is the lowest, and the mass transfer-based equations dominated the western desert. At a few locations in the middle and east regions of Egypt, temperature-based equations 
352 were found to be the best whereas the radiation-based equations were the best in the nearby 353 locations. However, it was found that the $2^{\text {nd }}$ best equation for most of these locations was a 354 radiation-based equation. For example, station no 27 on the Red Sea coast had Papadakis (KGE 355 0.86) as the best equation followed closely by the radiation-based Caprio equation (KGE 0.85). 356 The same was observed for station no. 21 at Cairo where Ritchie was the $2^{\text {nd }}$ best. Furthermore, 357 station no 31 in Saint Catherine Mount where Caprio equation had a close skill to Kharrufa 358 equation.

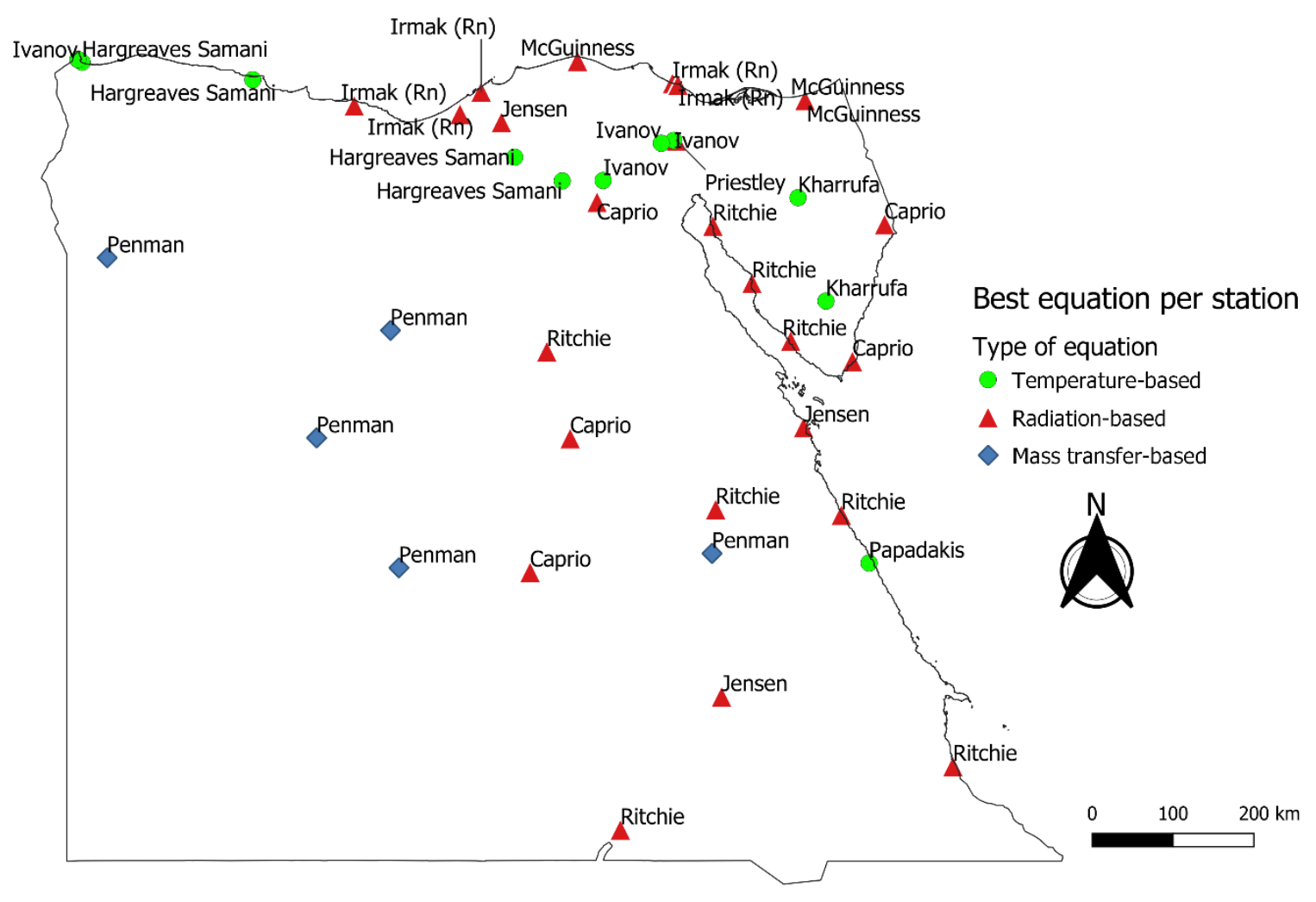

Figure 5. Spatial distribution of the best performing empirical equation at each station location.

\subsection{Evaluation of AI models}

Figure 6 presents box-and-whiskers plots to show the distribution of the available records from 364 the 41 meteorological stations for the four climatic variables (i.e., $T_{\max }, T_{\min }, \mathrm{U}_{2}$, and $\mathrm{RH}$ ). 365 Furthermore, the figure presents the distributions of $70 \%$ of the available records which were 366 chosen randomly and used in the training stage, as well as the remaining 30\% which were used in 367 the testing stage of the 20 AI models. The training set contains $70 \%$ (301824 daily data) of 

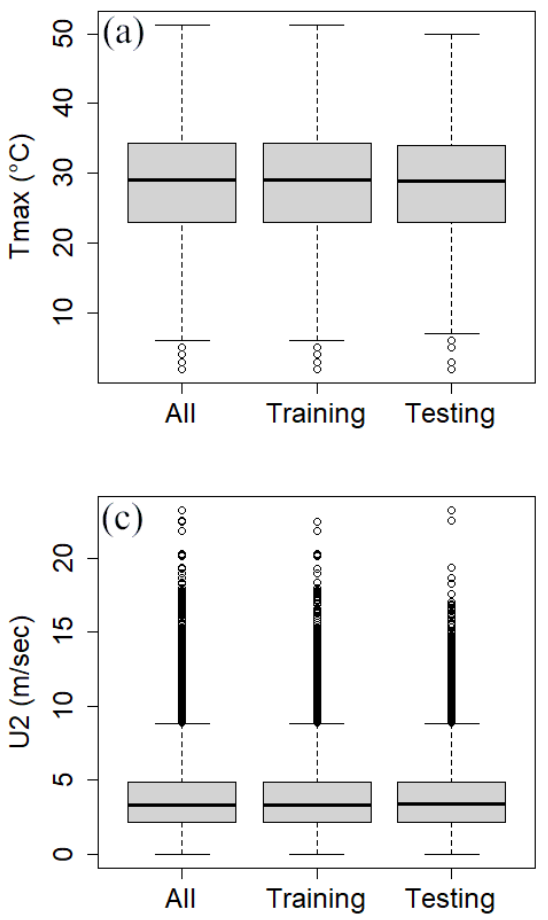
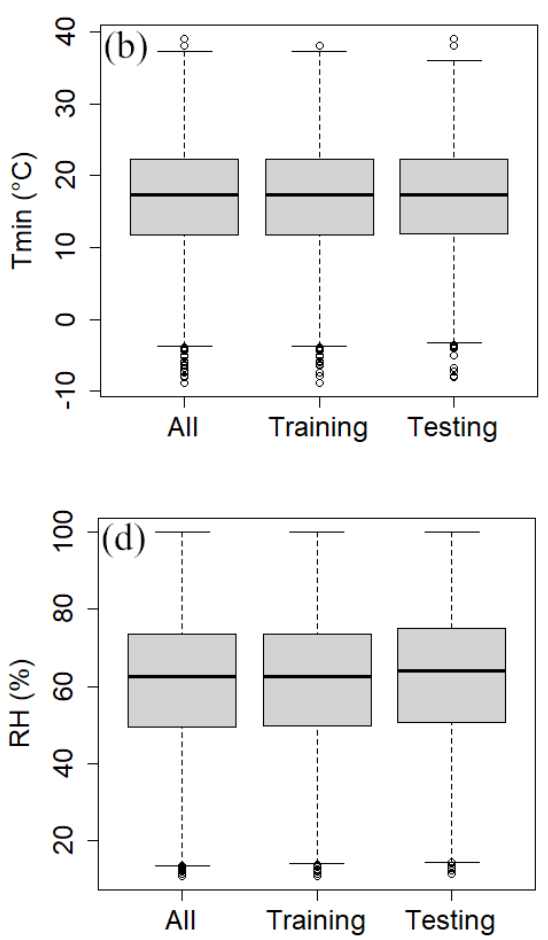

372 Figure 6. Data ranges for all records from 41 stations, and for data used in training and testing 373 stages for (a) maximum temperature $\left({ }^{\circ} \mathrm{C}\right)$, (b) minimum temperature $\left({ }^{\circ} \mathrm{C}\right),(\mathrm{c})$ wind speed $(\mathrm{m} / \mathrm{s})$, 374 and (d) relative humidity (\%).

375

376

377

378

379

380

381

382

383

384

385

In this study, 20 models were developed using five AI algorithms having four different combinations of the model's inputs to estimate the FAO56-PM ETo. Figure 7 illustrates the FAO56-PM ETo and simulated $\mathrm{ET}_{\mathrm{o}}$ from AI models, each row represents the same algorithm with the four different combinations of the model inputs. Combinations were utilized to estimate the daily $\mathrm{ET}_{\mathrm{o}}$ using the SVM, RF, GMDH-NN, MARS, and DENFIS. Twenty models were implemented to evaluate the performance of various climate data combinations. The first combination used two climatic data $\mathrm{T}_{\max }$ and $\mathrm{T}_{\min }$. The second and third combinations were generated by the addition of $U_{2}$ and $R H$ into the first combination, respectively. $U_{2}$ and $R H$ were added to the first combination to create a new fourth combination. The scatter plot in Figure 7 clearly shows that overall better performance of the $4^{\text {th }}$ combination compared to others. The $\mathrm{ET}_{\mathrm{o}}$ simulated by RF4 was considerably aligned with the diagonal line 1:1 and closely followed by the 
386 estimates of SVM4. Table 3 shows a comparison between models compared to FAO56-PM in 387 respect to KGE for the training and testing stages. Remarkably, the testing KGEs were $\geq$ than 388 those of training stage indicating a good generalization of models' performances. Furthermore, the 389 RF models presented the best results across the four combinations of input parameters. It was also 390 found that the $\mathrm{U}_{2}$ data when combined with $\mathrm{T}_{\max }$ and $\mathrm{T}_{\min }$ as input parameters led to improvement 391 in estimating $\mathrm{ET}_{\mathrm{o}}$ compared to using only $\mathrm{T}_{\max }$ and $\mathrm{T}_{\min }$. Furthermore, the improvement in the $2^{\text {nd }}$ 392 combination is better than in the $3^{\text {rd }}$ which used RH except in MARS and DENFIS. DENFIS in 393 the $1^{\text {st }}$ combination (DENFIS1) recorded testing KGE 0.83 which was equal to the RF1. SVM had 394 better testing KGEs following RF in the $2^{\text {nd }}, 3^{\text {rd }}$, and $4^{\text {th }}$ combinations which were $0.93,0.87$, and 3950.98 , respectively. DENFIS4 showed weak results compared to other corresponding models. 

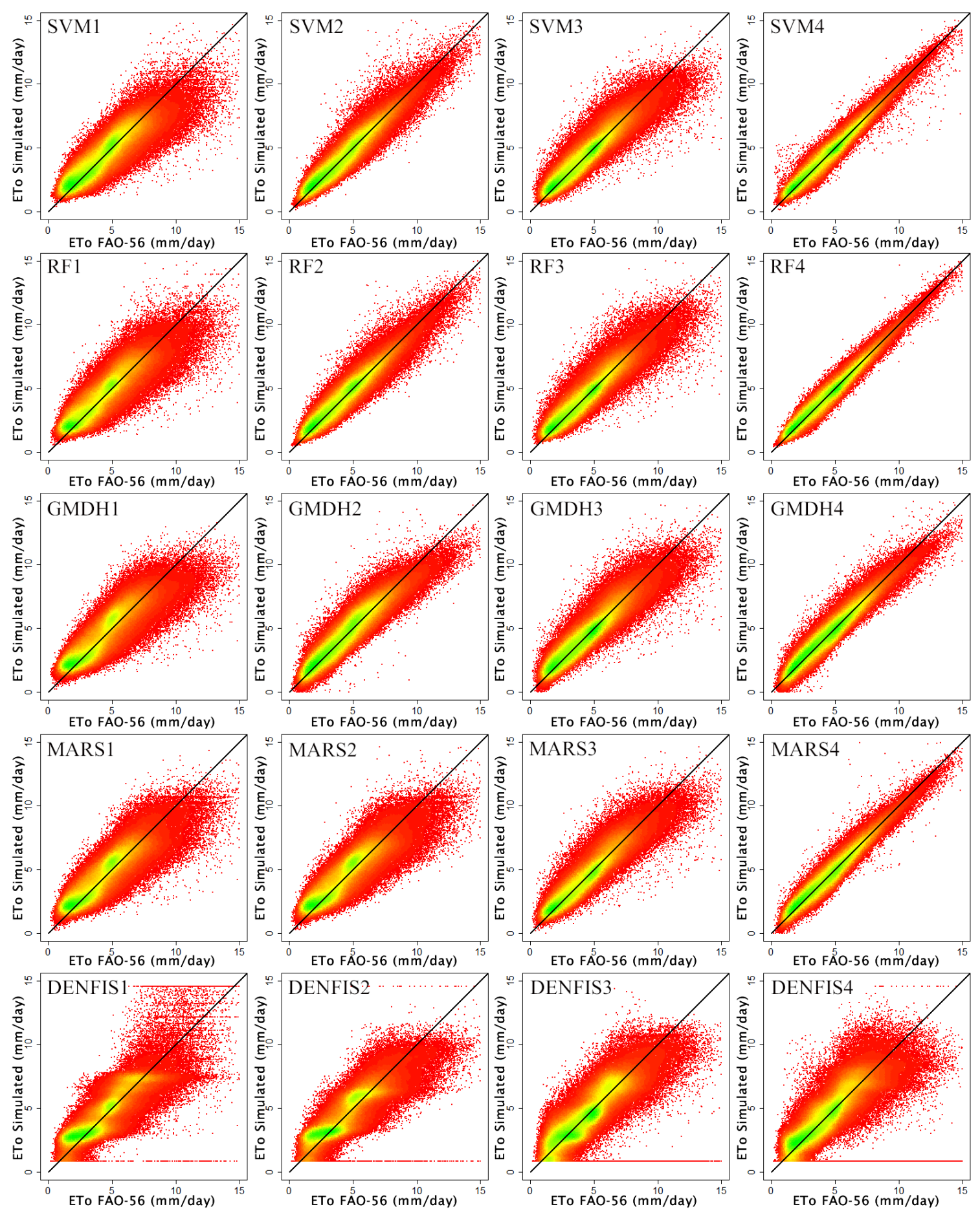
128864). 
Table 3. KGE values across the training and testing phase for each AI model.

\begin{tabular}{|c|c|c|c|}
\hline Model & $\begin{array}{l}\text { Model input } \\
\text { combination }\end{array}$ & $\begin{array}{c}\text { Training } \\
\text { KGE }\end{array}$ & $\begin{array}{c}\text { Testing } \\
\text { KGE }\end{array}$ \\
\hline \multicolumn{4}{|c|}{ Support vector machine } \\
\hline SVM 1 & $\mathrm{~T}_{\max }, \mathrm{T}_{\min }$ & 0.78 & 0.78 \\
\hline SVM 2 & $\mathrm{~T}_{\max }, \mathrm{T}_{\min }, \mathrm{U}_{2}$ & 0.93 & 0.93 \\
\hline SVM 3 & $\mathrm{~T}_{\max }, \mathrm{T}_{\min }, \mathrm{RH}$ & 0.86 & 0.87 \\
\hline SVM 4 & $\mathrm{~T}_{\max }, \mathrm{T}_{\min }, \mathrm{U}_{2}, \mathrm{RH}$ & 0.96 & 0.98 \\
\hline \multicolumn{4}{|c|}{ Random Forest } \\
\hline RF 1 & $T_{\max }, T_{\min }$ & 0.81 & 0.83 \\
\hline RF 2 & $\mathrm{~T}_{\max }, \mathrm{T}_{\min }, \mathrm{U}_{2}$ & 0.92 & 0.94 \\
\hline RF 3 & $\mathrm{~T}_{\max }, \mathrm{T}_{\min }, \mathrm{RH}$ & 0.87 & 0.92 \\
\hline RF 4 & $\mathrm{~T}_{\max }, \mathrm{T}_{\min }, \mathrm{U}_{2}, \mathrm{RH}$ & 0.97 & 0.99 \\
\hline \multicolumn{4}{|c|}{ Group method of data handling-Neural Network } \\
\hline GMDH 1 & $\mathrm{~T}_{\max }, \mathrm{T}_{\min }$ & 0.79 & 0.80 \\
\hline GMDH 2 & $\mathrm{~T}_{\max }, \mathrm{T}_{\min }, \mathrm{U}_{2}$ & 0.90 & 0.91 \\
\hline GMDH 3 & $\mathrm{~T}_{\max }, \mathrm{T}_{\min }, \mathrm{RH}$ & 0.87 & 0.87 \\
\hline GMDH 4 & $\mathrm{~T}_{\max }, \mathrm{T}_{\min }, \mathrm{U}_{2}, \mathrm{RH}$ & 0.95 & 0.95 \\
\hline \multicolumn{4}{|c|}{ Multivariate adaptive regression splines } \\
\hline MARS 1 & $\mathrm{~T}_{\max }, \mathrm{T}_{\min }$ & 0.80 & 0.80 \\
\hline MARS 2 & $\mathrm{~T}_{\max }, \mathrm{T}_{\min }, \mathrm{U}_{2}$ & 0.82 & 0.83 \\
\hline MARS 3 & $\mathrm{~T}_{\max }, \mathrm{T}_{\min }, \mathrm{RH}$ & 0.87 & 0.87 \\
\hline MARS 4 & $\mathrm{~T}_{\max }, \mathrm{T}_{\min }, \mathrm{U}_{2}, \mathrm{RH}$ & 0.96 & 0.96 \\
\hline \multicolumn{4}{|c|}{ Dynamic evolving neural fuzzy interference system } \\
\hline DENFIS 1 & $\mathrm{~T}_{\max }, \mathrm{T}_{\min }$ & 0.80 & 0.83 \\
\hline DENFIS 2 & $\mathrm{~T}_{\max }, \mathrm{T}_{\min }, \mathrm{U}_{2}$ & 0.78 & 0.85 \\
\hline DENFIS 3 & $\mathrm{~T}_{\max }, \mathrm{T}_{\min }, \mathrm{RH}$ & 0.81 & 0.86 \\
\hline DENFIS 4 & $\mathrm{~T}_{\max }, \mathrm{T}_{\min }, \mathrm{U}_{2}, \mathrm{RH}$ & 0.77 & 0.88 \\
\hline
\end{tabular}

401

402

403

404

405

406

407

408

\subsection{Estimating $E T_{0}$ in ungauged locations}

As presented in previous results the RF4 had the top performance compared to others besides its KGEs were even higher than those of empirical equations. Thus, the RF4 was adopted to estimate ETo in ungauged location in Egypt. The four input parameters required for RF4 were obtained from ERA5 to estimate daily $\mathrm{ET}_{\mathrm{o}}$ all over Egypt at $0.10^{\circ} \times 0.10^{\circ}$ horizontal resolution. Figure 8 shows the mean daily $\mathrm{ET}_{\mathrm{o}}$ spatial distribution for the period 1981-2020. The $\mathrm{ET}_{\mathrm{o}}$ ranges from 2.30 to $6.72 \mathrm{~mm} /$ day, which increases spatially by going southeast from the north of Egypt, except the Red Sea mountains chain. ETo rates in central Egypt range from 4.30 to $4.92 \mathrm{~mm} / \mathrm{day}$. 


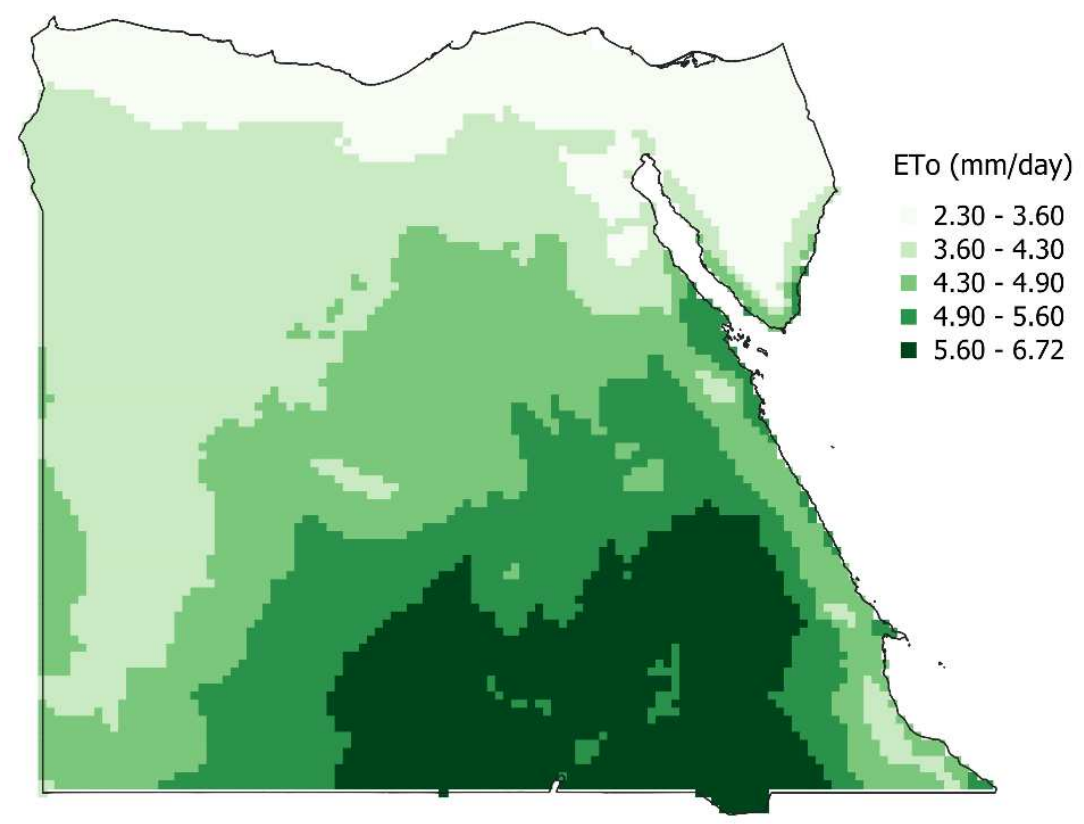

Figure 8. Mean daily ETo calculated over a period 1981-2020.

The daily $\mathrm{ET}_{\mathrm{o}}$ values for each grid point were cumulated and averaged during the years

413 from 1981 to 2020 to derive the annual averages. Time-series data were then utilized to estimate 414 rate of change and determine the significance of the shifts in the data. The color ramps in Figure 9 415 describe the rate of change obtained by Sen's slope estimator for ETo (Figure 9 e), as well as the 416 four predictors (Figure 9 a-d), to examine the driving factors. A dot in the middle of each grid 417 point indicates the significance of change as obtained using a modified MK test for a $95 \%$ level 418 of confidence.

419 The Sen's slope estimator test revealed an increase in the annual average $\mathrm{T}_{\max }$ and $\mathrm{T}_{\min }$ across all of Egypt's rates from 0.26 to 0.53 and 0.20 to $0.60{ }^{\circ} \mathrm{C} / \mathrm{dec}$ de, respectively. The largest 421 change in $T_{\max }$ occurred in the north and east of the Nile Delta. However, for $\mathrm{T}_{\min }$, it occurred in 422 the far south of Egypt. The modified MK test showed a significant decrease in RH in the northeast 423 of Egypt. The changes in RH were detected in the range of -1.13 to $-0.05 \% /$ decade. The highest 424 rate of decrease $-1.13 \% /$ decade was observed East of the Nile Delta and north of Sinai. The $\mathrm{U}_{2}$ 425 trend shows varieties of increases and decreases. However, the changes were only significant 426 mainly along the Red Sea shores and south of Sinai. As can be observed in Figure 9 (e), the changes 427 in $\mathrm{ET}_{\mathrm{o}}$ were found to be significantly increasing all over Egypt, with the highest change of 0.16$4280.18 \mathrm{~mm} /$ decade observed in the far southeast of Egypt. 
(a)

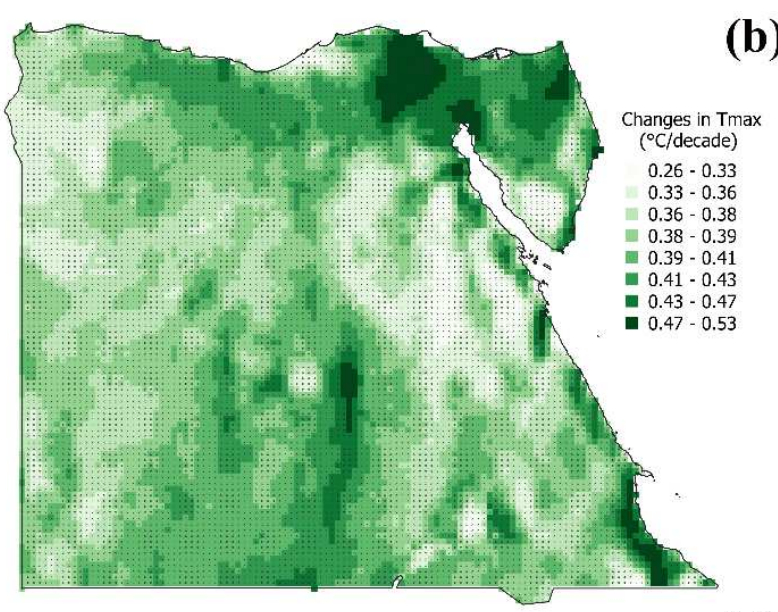

(c)

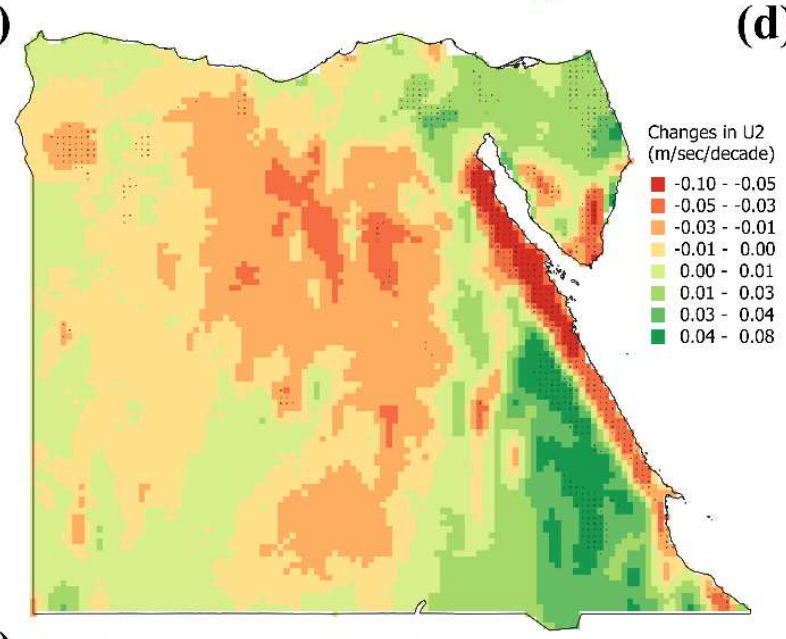

(e)

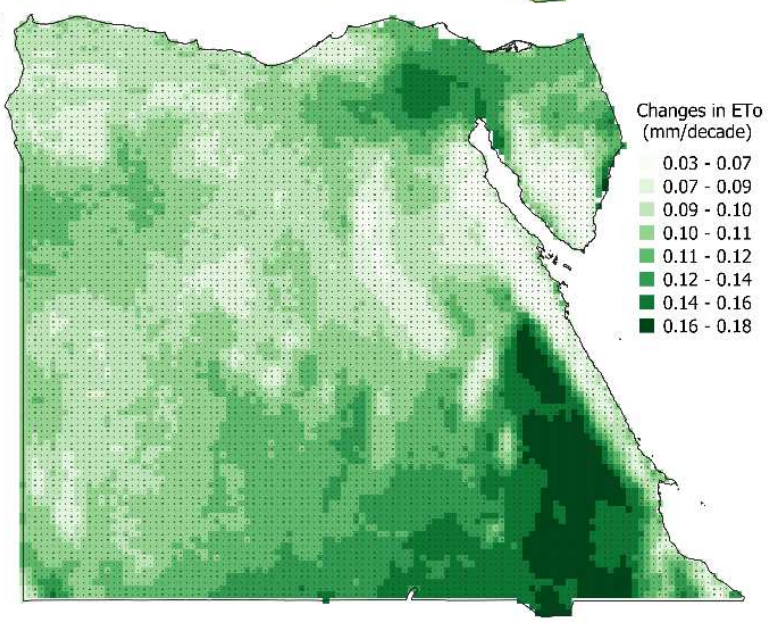

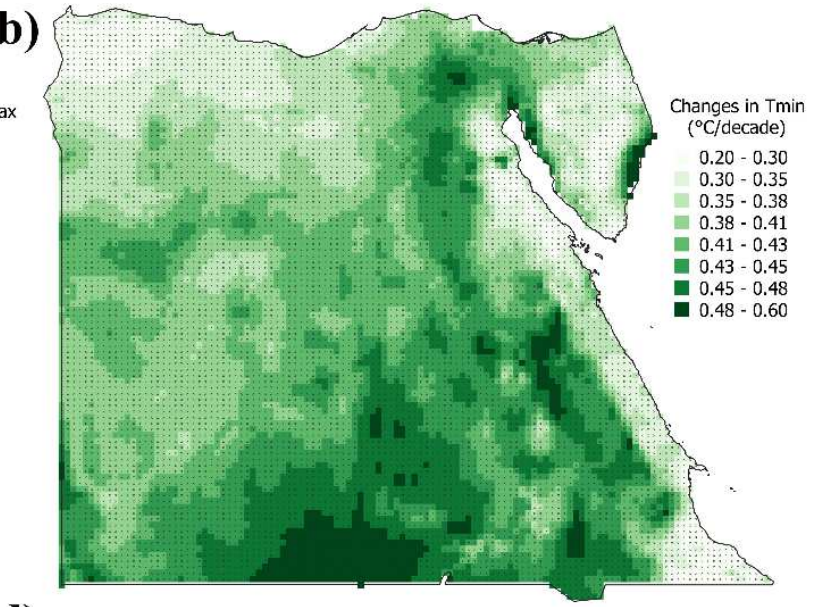

(d)

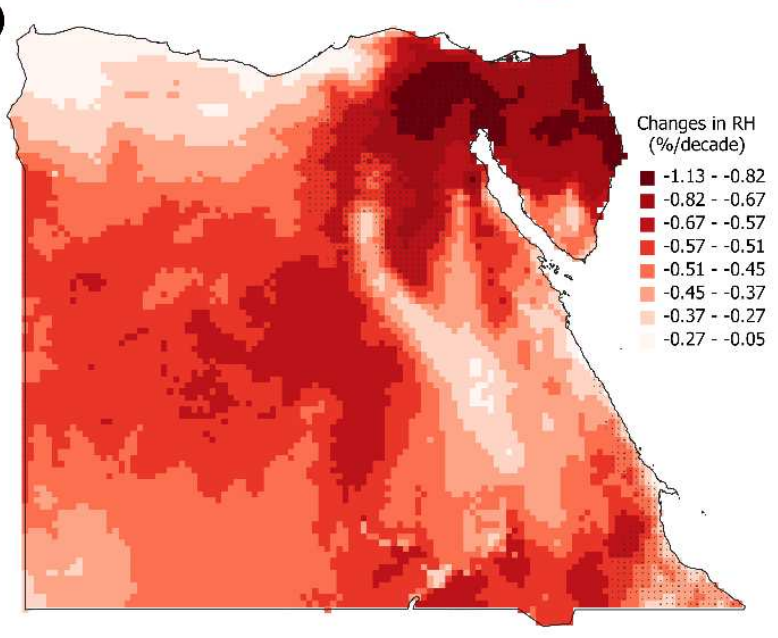

431 Figure 9. Spatial distributions of the rate of change in (a) $T_{\max }$, (b) $T_{\min }$, (c) $U_{2}$, (d) $R H$, and (e) $432 \mathrm{ET}_{\mathrm{o}}$ as estimated using the RF4 model. Color ramps indicate the rate of change obtained using 433 Sens's slope estimator. The significant changes $(p>0.05)$ are marked with a dot. 
436 Most of the previous studies had adopted several statistical metrics for the evaluation of either empirical equations or AI models in estimating the FAO56-PM ETo. The use of several metrics can generally produce a reliable assessment of modeling techniques rather than the use of a single metric. However, the use of several metrics may provide contradictory results due to the fact each metric reflects the state of specific statistical characteristics (e.g., error, association, etc.) (Hamed et al. 2022; Nashwan and Shahid 2019b). This study used only the KGE which is a composite metric that integrates estimates of bias, correlation, and variability, to gain the advantages of using multiple metrics while avoiding related complexities in using multiples.

Based on median KGE values, the radiation-based Ritchie empirical equation was found the best (median KGE 0.75) to replicate the FAO56-PM estimates of daily ETo. It was followed by the temperature-based Hargreaves-Samani and the radiation-based Priestley et al. (median KGE 0.73 and 0.71 , respectively). Ritchie was found the best based on station-wise ranking followed by Penman, Caprio, and Irmak (-Rn). Also, the results proved the better performance of the RF models in general compared to other AI algorithms. Thus, this study recommends Ritchie equation as a substitute method for the FAO56-PM when required observations are limited.

The present study revealed that Ritchie equation, which is a radiation-based method, had a superior performance in modeling $\mathrm{ET}_{\mathrm{o}}$ in the arid climate of Egypt. Furthermore, the study results illustrated the overall better performance of radiation-based equations than temperature- and masstransfer-based equations. These findings agree with previous studies' results. Del Cerro et al. (2021) evaluated the performance of various radiation- and temperature-based empirical equations in the semi-arid region of south India and found that Ritchie had performed the best. Furthermore, they concluded that radiation-based equations are best suited to estimate $\mathrm{ET}_{\mathrm{o}}$ in the study region. Also, Tabari et al. (2013) and Sharafi and Ghaleni (2021) concluded that the radiation-based models were the best-suited equations, while mass transfer-based equations had the worst performances in Iran. Tabari et al. (2012) found the Ritchie equation gives an acceptable performance in modeling crop ET Tabriz, Iran. Farzanpour et al. (2018) proved that a calibrated 463 version of Ritchie equation was among the best in semi-arid regions in Iran. Tikhamarine et al. (2020) also confirmed that Ritchie equation had a reliable estimate of $\mathrm{ET}_{\mathrm{o}}$ in Algeria. On the contrary, Ritchie equation was found to be the worst at estimating ET $\mathrm{o}$ in other climate types, rather than arid, as in Muhammad et al. (2019) and Feng et al. (2016). 
The finding of the present study revealed an overall good performance of AI models compared to empirical equations in simulating daily mean $\mathrm{ET}_{\mathrm{o}}$ in arid Egypt. Besides, this study found that the models having $\mathrm{U}_{2}$ and $\mathrm{RH}$ as input parameters with $\mathrm{T}_{\max }$ and $\mathrm{T}_{\min }$ were better in performance. This agrees with the finding of Mattar (2018) in Egypt. Furthermore, this study found that including $\mathrm{U}_{2}$ gave better performance than including $\mathrm{RH}$ along with $\mathrm{T}_{\max }$ and $\mathrm{T}_{\min }$.

Among AI models, the RF models were the most accurate, closely followed by SVM. These 472 findings can be confirmed by previous studies. Wen et al. (2015), Mehdizadeh et al. (2017), and 473 Adnan et al. (2021) confirm that, overall, the soft computing approach performs better than 474 empirical equations, which is in agreement with the present study finding. Furthermore, 475 Mehdizadeh et al. (2017) reported the strong ability of SVM- polynomial in estimating monthly $476 \mathrm{ET}_{\mathrm{o}}$ in Iran. Furthermore, GMDH-NN had acceptable performance, as found by Adnan et al. 477 (2021) in Turkey. Also, this study found that DINFIS models were the worst among the applied 478 algorithms, as was similarly reported by Muhammad Adnan et al. (2020) when modeling monthly $479 \quad \mathrm{ET}_{\mathrm{o}}$ in China.

The main advantage of using RF models is their flexibility, meaning that when the dimensions of the characteristic parameters increase, the RF method does not generate overfitting, but better 482 results are still achieved. The RF algorithm outperforms SVM when tested with identical 483 characteristic parameters (Jia et al. 2013). Han et al. (2018) conducted a comparative analysis to evaluate the behavior of RF and showed that RF has outstanding properties in terms of classification accuracy, stability, and robustness to characteristics, as demonstrated by the comparison. In particular, they discovered that RF is significantly better when the training samples are constrained in a number of analytical studies. These may be the reasons why the RF models outperformed other algorithms. relatively low $\mathrm{ET}_{\mathrm{o}}$ (north of Egypt) are experiencing a higher increase. Meanwhile, locations of high $\mathrm{ET}_{\mathrm{o}}$ (south and east of Egypt) are experiencing an equal and lower rate of increase. This indicates that $\mathrm{ET}_{\mathrm{o}}$ shall be overall higher in future climate states. This may have severe 494 consequences for agriculture and water resources in Egypt in the future. The high rate of evaporation has already had a significant impact on Lake Nasser (Egypt's national reserve of fresh 495 water) and thus the Egyptian water budget (Salih et al. 2019). 


\section{Conclusions}

Accurate estimation of $\mathrm{ET}_{\mathrm{o}}$ using the standard FAO56-PM is challenging when required climate data isn't available as in most regions around the globe. In this study, the abilities of five AI algorithms (i.e., SVM, RF, MARS, GMDH-NN, and DENFIS) and 31 empirical equations in modeling daily $\mathrm{ET}_{\mathrm{o}}$ compared to the FAO56-PM equation were evaluated. First, at 41 locations covering Egypt, the KGE evaluation results showed that Ritchie had the best overall performance (median KGE 0.75) and found the best at the highest number of stations based on a station-wise ranking compared to others. In contrast to the several meteorological variables required for the FAO56-PM computation of ET $\mathrm{E}_{\mathrm{o}}$, the Ritchie equation just requires $\mathrm{T}_{\max }, \mathrm{T}_{\min }$, and $\mathrm{R}_{\mathrm{s}}$. The result illustrates that Ritchie equation can be used as a substitute for FAO56-PM when data is scarce. Secondly, different combinations of $\mathrm{T}_{\max }, \mathrm{T}_{\min }, \mathrm{U}_{2}$, and $\mathrm{RH}$ were used as inputs to train $\mathrm{AI}$ models to target the FAO56-PM ETo. The RF model was generally the most accurate in predicting daily mean $\mathrm{ET}_{\mathrm{o}}$, closely followed by SVM, whereas DENFIS provided the worst prediction at the third and fourth combinations of input variables. Thus, this study recommends using the RF model in predicting $\mathrm{ET}_{\mathrm{o}}$. According to the findings of this study, the RF1 model, which requires only maximum and minimum temperature, can be employed for worst-case scenarios. Using the RF model, irrigation schedulers can get an accurate estimate of $\mathrm{ET}_{\mathrm{o}}$ in Egypt, without the need for the full set of climatic data. Thirdly, the RF4 model was used to generate a 0.1-degree resolution of $\mathrm{ET}_{\mathrm{o}}$, all over Egypt, using ERA5 data. Finally, Sen's slope estimator and modified Mann-Kendall test showed a significant change in $\mathrm{ET}_{\mathrm{o}}$ in most locations in Egypt over the past 40 years.

Considering the lack of reliable observation records for the required inputs of the FAO56PM in most developing countries, the present study shall be useful for determining $\mathrm{ET}_{\mathrm{o}}$ in arid climates, such as Egypt, using simpler and more accurate methods. Furthermore, this study enables peers to produce better estimations of drought and aridity status in Egypt, which employs common methods such as standard precipitation evaporation index and aridity index. Thus, it can provide enhanced strategies for the adaptation and mitigation of such events. Locally, irrigation schedulers can get an accurate estimate of $\mathrm{ET}_{\mathrm{o}}$, without the need for the full set of climatic data.

The developed high resolution $\left(0.10^{\circ} \times 0.10^{\circ}\right)$ daily estimation of $\mathrm{ET}_{\mathrm{o}}$ is freely available online (DOI:10.6084/m9.figshare.18551084) in Comma-Separated Values (CSV) format. The daily records cover the land of Egypt and temporally span from 1981 to 2020. 
527 Future works may investigate the future change in $\mathrm{ET}_{\mathrm{o}}$ regionally in Egypt, using the state-of528 art Coupled Model Intercomparison Project phase 6 (CMIP6) models with the use of RF models 529 of this study. Also, the high-resolution data can be used in downscaling and bias-correction of 530 CMIP6 model estimations. Furthermore, peers can provide a locally calibrated version of the 531 Ritchie equation in Egypt.

532

\section{Funding}

534 The authors declare that no funds, grants, or other support were received during the preparation of 535 this manuscript.

\section{Competing Interests}

537 The authors have no relevant financial or non-financial interests to disclose.

538 Author Contributions

539 All authors contributed to the study's conception and design. Material preparation, data collection 540 methodology, and analysis were performed by Mohamed Tarek Sobh and Mohamed Salem 541 Nashwan. The first draft of the manuscript was written by Mohamed Tarek Sobh and Mohamed 542 Salem Nashwan and all authors commented on previous versions of the manuscript. All authors 543 read and approved the final manuscript. 


\section{References}

546

547

548

549

550

551

552

553

554

555

556

557

558

559

560

561

562

563

564

565

566

567

568

569

570

571

572

573

574

575

576

577

578

579

580

581

582

583

584

585

586

587

588

589

590

Abd el-wahed MH, Snyder RL (2015) Calculating sunshine hours and reference evapotranspiration in arid regions when solar radiation data are limited Irrigation and Drainage 64:419-425

Abtew W (1996) Evapotranspiration Measurements and Modeling for Three Wetland Systems in South Florida Journal of the American Water Resources Association 32:465-473 doi:10.1111/j.17521688.1996.tb04044.x

AbuZeid KM (2020) Existing and Recommended Water Policies in Egypt. In: Zekri S (ed) Water Policies in MENA Countries. Springer International Publishing, Cham, pp 47-62. doi:10.1007/978-3-03029274-4_3

Adnan RM, Heddam S, Yaseen ZM, Shahid S, Kisi O, Li B (2021) Prediction of Potential Evapotranspiration Using Temperature-Based Heuristic Approaches Sustainability 13:297

Albrecht F (1950) Die Methoden zur Bestimmung der Verdunstung der natürlichen Erdoberfläche Archiv für Meteorologie, Geophysik und Bioklimatologie, Serie B 2:1-38 doi:10.1007/bf02242718

Alizamir M, Kisi O, Muhammad Adnan R, Kuriqi A (2020) Modelling reference evapotranspiration by combining neuro-fuzzy and evolutionary strategies Acta Geophysica 68:1113-1126

Allen RG, Pereira LS, Raes D, Smith M (1998) Crop Evapotranspiration: Guidelines for computing crop water requirements FAO Irrigation and Drainage Paper 56

Ångström A (1924) Solar and terrestrial radiation. Report to the international commission for solar research on actinometric investigations of solar and atmospheric radiation, QJ Roy. Meteor. Soc., 50, 121-126 ChineseByun HR, Wilhite DA (1999) Objective quantification of drought severity and duration J Clim

Baier W, Robertson GW (1965) Estimation of latent evaporation from simple weather observations Canadian journal of plant science 45:276-284

Bojanowski JS, Vrieling A, Skidmore AK (2013) Calibration of solar radiation models for Europe using Meteosat Second Generation and weather station data Agricultural and Forest Meteorology 176:1-9 doi:https://doi.org/10.1016/i.agrformet.2013.03.005

Brockamp B, Wenner H (1963) Verdunstungsmessungen auf den Steiner See bei Münster Dt Gewässerkundl Mitt 7:149-154

Caprio JM (1974) The solar thermal unit concept in problems related to plant development and potential evapotranspiration. In: Phenology and seasonality modeling. Springer, pp 353-364

Dalton J (1802) Experimental essays on the constitution of mixed gases; on the force of steam or vapor from water and other liquids in different temperatures, both in a Torricellian vacuum and in air; on evaporation and on the expansion of gases by heat Memoirs of the Literary and Philosophical Society of Manchester 5:535-602

Del Cerro RTG, Subathra M, Kumar NM, Verrastro S, George ST (2021) Modelling the daily reference evapotranspiration in semi-arid region of South India: A case study comparing ANFIS and empirical models Information Processing in Agriculture 8:173-184

Doorenbos J, Pruitt W (1977) Crop water requirements. FAO irrigation and drainage paper 24 Land and Water Development Division, FAO, Rome 144

Farzanpour H, Shiri J, Sadraddini AA, Trajkovic S (2018) Global comparison of 20 reference evapotranspiration equations in a semi-arid region of Iran Hydrology Research 50:282-300 doi:10.2166/nh.2018.174

Feng Y, Cui N, Zhao L, Hu X, Gong D (2016) Comparison of ELM, GANN, WNN and empirical models for estimating reference evapotranspiration in humid region of Southwest China Journal of Hydrology 536:376-383 doi:https://doi.org/10.1016/j.jhydrol.2016.02.053

Gangopadhyaya M (1966) Measurement and estimation of evaporation and evapotranspiration 
Gavili S, Sanikhani H, Kisi O, Mahmoudi MH (2018) Evaluation of several soft computing methods in monthly evapotranspiration modelling Meteorological Applications 25:128-138

Gleixner S, Demissie T, Diro GT (2020) Did ERA5 Improve Temperature and Precipitation Reanalysis over East Africa? Atmosphere 11:996

Gonzalez del Cerro RT, Subathra MSP, Manoj Kumar N, Verrastro S, Thomas George S (2021) Modelling the daily reference evapotranspiration in semi-arid region of South India: A case study comparing ANFIS and empirical models Information Processing in Agriculture 8:173-184 doi:https://doi.org/10.1016/j.inpa.2020.02.003

Hamed KH (2019) Stochastic Investigation of the GERD-AHD Interaction Through First Impoundment and Beyond. In: Negm AM, Abdel-Fattah S (eds) Grand Ethiopian Renaissance Dam Versus Aswan High Dam: A View from Egypt. The Handbook of Environmental Chemistry. Springer International Publishing, Cham, pp 95-117. doi:10.1007/698_2017_125

Hamed KH, Rao AR (1998) A modified Mann-Kendall trend test for autocorrelated data Journal of Hydrology 204:182-196 doi:Doi 10.1016/S0022-1694(97)00125-X

Hamed MM, Nashwan MS, Shahid S (2021a) Intercomparison of historical simulation and future projections of rainfall and temperature by CMIP5 and CMIP6 GCMs over Egypt International Journal of Climatology

Hamed MM, Nashwan MS, Shahid S (2021b) A novel selection method of CMIP6 GCMs for robust climate projection International Journal of Climatology n/a doi:https://doi.org/10.1002/joc.7461

Hamed MM, Nashwan MS, Shahid S (2021c) Performance evaluation of reanalysis precipitation products in Egypt using fuzzy entropy time series similarity analysis International Journal of Climatology 41:5431-5446 doi:https://doi.org/10.1002/joc.7286

Hamed MM, Nashwan MS, Shahid S, Ismail Tb, Wang X-j, Dewan A, Asaduzzaman M (2022) Inconsistency in historical simulations and future projections of temperature and rainfall: $A$ comparison of CMIP5 and CMIP6 models over Southeast Asia Atmospheric Research 265:105927 doi:https://doi.org/10.1016/i.atmosres.2021.105927

Hamon WR (1963) Computation of direct runoff amounts from storm rainfall International Association of Scientific Hydrology Publication 63:52-62

Han T, Jiang D, Zhao Q, Wang L, Yin K (2018) Comparison of random forest, artificial neural networks and support vector machine for intelligent diagnosis of rotating machinery Transactions of the Institute of Measurement and Control 40:2681-2693

Hargreaves GH, Samani ZA (1985) Reference crop evapotranspiration from temperature Applied Engineering in Agriculture 1:96-99

Iqbal Z, Shahid S, Ahmed K, Ismail T, Nawaz N (2019) Spatial distribution of the trends in precipitation and precipitation extremes in the sub-Himalayan region of Pakistan Theoretical and Applied Climatology doi:10.1007/s00704-019-02773-4

Irmak S, Allen R, Whitty E (2003) Daily grass and alfalfa-reference evapotranspiration estimates and alfalfa-to-grass evapotranspiration ratios in Florida Journal of Irrigation and Drainage Engineering 129:360-370 doi:10.1061/(Asce)0733-9437(2003)129:5(360)

Ismail T, Harun S, Zainudin ZM, Shahid S, Fadzil AB, Sheikh UU (2017) Development of an optimal reservoir pumping operation for adaptation to climate change KSCE Journal of Civil Engineering 21:467-476 doi:10.1007/s12205-016-0641-z

Jensen ME, Haise HR (1963) Estimating evapotranspiration from solar radiation Proceedings of the American Society of Civil Engineers, Journal of the Irrigation and Drainage Division 89:15-41 Jia S, Hu X, Sun L (2013) The comparison between random forest and support vector machine algorithm for predicting $\beta$-hairpin motifs in proteins Engineering 5:391

Jones C (1990) Crop growth models Management of Farm Irrigated Systems 
Kasabov NK, Qun S (2002) DENFIS: dynamic evolving neural-fuzzy inference system and its application for time-series prediction IEEE Transactions on Fuzzy Systems 10:144-154 doi:10.1109/91.995117

Kendall MG (1948) Rank correlation methods. Hafner Publishing Co., Oxford, England Kharrufa N (1985) Simplified equation for evapotranspiration in arid regions Beiträge zur Hydrologie 5:39-47

Knoben WJ, Freer JE, Woods RA (2019) Inherent benchmark or not? Comparing Nash-Sutcliffe and Kling-Gupta efficiency scores Hydrology and Earth System Sciences 23:4323-4331 doi:https://doi.org/10.5194/hess-23-4323-2019

Linacre ET (1977) A simple formula for estimating evaporation rates in various climates, using temperature data alone Agricultural meteorology 18:409-424

Lompar M, Lalić B, Dekić L, Petrić M (2019) Filling gaps in hourly air temperature data using debiased ERA5 data Atmosphere 10:13

Mahringer W (1970) Verdunstungsstudien am neusiedler See Archiv für Meteorologie, Geophysik und Bioklimatologie, Serie B 18:1-20

Makkink G (1957) Testing the Penman formula by means of lysimeters Journal of the Institution of Water Engineerrs 11:277-288

Mann HB (1945) Nonparametric Tests Against Trend Econometrica 13:245-259 doi:10.2307/1907187

Mattar MA (2018) Using gene expression programming in monthly reference evapotranspiration modeling: A case study in Egypt Agricultural Water Management 198:28-38 doi:10.1016/j.agwat.2017.12.017

McGuinness JL, Bordne EF (1972) A comparison of lysimeter-derived potential evapotranspiration with computed values. vol 1452. US Dept. of Agriculture,

Mehdizadeh S, Behmanesh J, Khalili K (2017) Using MARS, SVM, GEP and empirical equations for estimation of monthly mean reference evapotranspiration Computers and Electronics in Agriculture 139:103-114 doi:10.1016/j.compag.2017.05.002

Meyer A (1926) Über einige Zusammenhänge zwischen Klima und Boden in Europa vol 2. Chem Erde.

Mohsenipour M, Shahid S, Chung ES, Wang XJ (2018) Changing Pattern of Droughts during Cropping Seasons of Bangladesh Water Resources Management 32:1555-1568 doi:10.1007/s11269-0171890-4

Muhammad Adnan R, Chen Z, Yuan X, Kisi O, El-Shafie A, Kuriqi A, Ikram M (2020) Reference Evapotranspiration Modeling Using New Heuristic Methods Entropy 22:547

Muhammad MKI, Nashwan MS, Shahid S, Ismail Tb, Song YH, Chung E-S (2019) Evaluation of empirical reference evapotranspiration models using compromise programming: a case study of Peninsular Malaysia Sustainability 11:4267

Nashwan MS, Shahid S (2019a) Spatial distribution of unidirectional trends in climate and weather extremes in Nile river basin Theoretical and Applied Climatology 137:1181-1199 doi:10.1007/s00704-018-2664-5

Nashwan MS, Shahid S (2019b) Symmetrical uncertainty and random forest for the evaluation of gridded precipitation and temperature data Atmospheric Research 230:104632 doi:10.1016/j.atmosres.2019.104632

Nashwan MS, Shahid S, Dewan A, Ismail T, Alias N (2020) Performance of five high resolution satellitebased precipitation products in arid region of Egypt: An evaluation Atmospheric Research 236:104809 doi:10.1016/j.atmosres.2019.104809

Nashwan MS, Shahid S, Wang XJ (2019) Uncertainty in Estimated Trends Using Gridded Rainfall Data: A Case Study of Bangladesh Water 11:349 doi:10.3390/w11020349

Nikiel CA, Eltahir EAB (2021) Past and future trends of Egypt's water consumption and its sources Nature Communications 12:4508 doi:10.1038/s41467-021-24747-9 
Omran E-SE, Negm AM (2020) Egypt's Environment from Satellite. In: Elbeih SF, Negm AM, Kostianoy A (eds) Environmental Remote Sensing in Egypt. Springer International Publishing, Cham, pp 2391. doi:10.1007/978-3-030-39593-3_3

Papadakis J (1965) Crop ecologic survey in relation to agricultural development of Western Pakistan. Draft report

Penman HL (1948) Natural evaporation from open water, bare soil and grass Proceedings of the Royal Society of London Series A Mathematical and Physical Sciences 193:120-145 doi:DOI 10.1098/rspa.1948.0037

Prescott J (1940) Evaporation from a water surface in relation to solar radiation Trans Roy Soc S Aust 46:114-118

Priestley CHB, Taylor R (1972) On the assessment of surface heat flux and evaporation using large-scale parameters Monthly weather review 100:81-92

Ravazzani G, Corbari C, Morella S, Gianoli P, Mancini M (2011) Modified Hargreaves-Samani equation for the assessment of reference evapotranspiration in Alpine river basins Journal of irrigation and drainage engineering 138:592-599

Rohwer C (1931) Evaporation from free water surfaces. vol 271. US Department of Agriculture, Romanenko V (1961) Computation of the autumn soil moisture using a universal relationship for a large area Proc of Ukrainian Hydrometeorological Research Institute 3:12-25

Roudier P, Ducharne A, Feyen L (2014) Climate change impacts on runoff in West Africa: a review Hydrology and Earth System Sciences 18:2789-2801

Sa'adi Z, Shahid S, Ismail T, Chung E-S, Wang X-J (2017) Trends analysis of rainfall and rainfall extremes in Sarawak, Malaysia using modified Mann-Kendall test Meteorology and Atmospheric Physics:115 doi:10.1007/s00703-017-0564-3

Salam R, Islam ARMT, Pham QB, Dehghani M, Al-Ansari N, Linh NTT (2020) The optimal alternative for quantifying reference evapotranspiration in climatic sub-regions of Bangladesh Scientific Reports 10:20171 doi:10.1038/s41598-020-77183-y

Salih SQ et al. (2019) Viability of the advanced adaptive neuro-fuzzy inference system model on reservoir evaporation process simulation: case study of Nasser Lake in Egypt Engineering Applications of Computational Fluid Mechanics 13:878-891 doi:10.1080/19942060.2019.1647879

Salman SA, Shahid S, Ismail T, Ahmed K, Chung E-S, Wang X-J (2019) Characteristics of Annual and Seasonal Trends of Rainfall and Temperature in Iraq Asia-Pacific Journal of Atmospheric Sciences 55:429-438 doi:10.1007/s13143-018-0073-4

Sanikhani H, Kisi O, Maroufpoor E, Yaseen ZM (2019) Temperature-based modeling of reference evapotranspiration using several artificial intelligence models: application of different modeling scenarios Theoretical and Applied Climatology 135:449-462 doi:10.1007/s00704-018-2390-z

Schendel U (1967) Vegetationswasserverbrauch und-wasserbedarf Habilitation, Kiel 137

Sen PK (1968) Estimates of the Regression Coefficient Based on Kendall's Tau Journal of the American Statistical Association 63:1379-1389 doi:10.1080/01621459.1968.10480934

Shahid S (2011) Impact of climate change on irrigation water demand of dry season Boro rice in northwest Bangladesh Climatic Change 105:433-453 doi:10.1007/s10584-010-9895-5

Shahid S, Khairulmaini OS (2009) Spatio-temporal variability of rainfall over Bangladesh during the time period 1969-2003 Asia-Pacific Journal of Atmospheric Sciences 43:375-389

Sharafati A, Nabaei S, Shahid S (2019) Spatial assessment of meteorological drought features over different climate regions in Iran International Journal of Climatology n/a:1- 21 doi:10.1002/joc.6307

Sharafi S, Ghaleni MM (2021) Calibration of empirical equations for estimating reference evapotranspiration in different climates of Iran Theoretical and Applied Climatology:1-15 
Sharaky AM, Hamed KH, Mohamed AB (2019) Model-Based Optimization for Operating the Ethiopian Renaissance Dam on the Blue Nile River. In: Negm AM, Abdel-Fattah S (eds) Grand Ethiopian Renaissance Dam Versus Aswan High Dam: A View from Egypt. Springer International Publishing, Cham, pp 119-148. doi:10.1007/698_2017_188

Szasz G (1973) A potenciális párolgás meghatározásának új módszere. Hidrológiai Közlöny:435-442

Tabari H, Grismer ME, Trajkovic S (2013) Comparative analysis of 31 reference evapotranspiration methods under humid conditions Irrigation Sci 31:107-117 doi:10.1007/s00271-011-0295-z

Tabari H, Martinez C, Ezani A, Hosseinzadeh Talaee P (2012) Applicability of support vector machines and adaptive neurofuzzy inference system for modeling potato crop evapotranspiration Irrigation Sci 31:575-588 doi:10.1007/s00271-012-0332-6

Tikhamarine Y, Malik A, Souag-Gamane D, Kisi O (2020) Artificial intelligence models versus empirical equations for modeling monthly reference evapotranspiration Environmental Science and Pollution Research 27:30001-30019

Trabert W (1896) Neue Beobachtungen über Verdampfungsgeschwindigkeiten [New Observations on Evaporation Rates.] vol 13. Meteorologische Zeitschrift.

Trajkovic S (2007) Hargreaves versus Penman-Monteith under humid conditions Journal of Irrigation and Drainage Engineering 133:38-42 doi:10.1061/(Asce)0733-9437(2007)133:1(38)

Turc $L$ Water requirements assessment of irrigation, potential evapotranspiration: simplified and updated climatic formula. In: Annales Agronomiques, 1961. pp 13-49

Wen X, Si J, He Z, Wu J, Shao H, Yu H (2015) Support-Vector-Machine-Based Models for Modeling Daily Reference Evapotranspiration With Limited Climatic Data in Extreme Arid Regions Water Resources Management 29:3195-3209 doi:10.1007/s11269-015-0990-2

Yassen AN, Nam W-H, Hong E-M (2020) Impact of climate change on reference evapotranspiration in Egypt CATENA 194:104711 doi:https://doi.org/10.1016/j.catena.2020.104711

Ye L, Zahra MMA, Al-Bedyry NK, Yaseen ZM (2022) Daily scale evapotranspiration prediction over the coastal region of southwest Bangladesh: new development of artificial intelligence model Stochastic Environmental Research and Risk Assessment 36:451-471 doi:10.1007/s00477-02102055-4

Yu H, Wen X, Li B, Yang Z, Wu M, Ma Y (2020) Uncertainty analysis of artificial intelligence modeling daily reference evapotranspiration in the northwest end of China Computers and Electronics in Agriculture 176:105653 doi:https://doi.org/10.1016/j.compag.2020.105653 